\title{
Liquefaction susceptibility of central Kerala
}

\author{
M. Akhila ${ }^{1}$ (D) K. Rangaswamy ${ }^{1} \cdot$ N. Sankar ${ }^{1}$
}

(c) Springer Nature Switzerland AG 2019

\begin{abstract}
This paper aims to analyze the liquefaction susceptibility of central Kerala (Ernakulam), India. This region is selected as it is the most seismically active zone in Kerala. Soil type details and standard penetration test values of the area were collected using field methods for the analysis. Liquefaction analysis was carried out, for a PGA of $0.2 \mathrm{~g}$ and earthquake magnitude (to be specific, moment magnitude, $M_{w}$ ) of six, using NovoLiq software. It was found that the majority of the sites selected are prone to liquefaction. The results are expressed in terms of factor of safety against liquefaction, probability of liquefaction, lateral spreading and vertical settlement. Also, the effect of variation in PGA, earthquake magnitude and ground water table on the factor of safety against liquefaction has been elaborated.
\end{abstract}

Keywords Clay · Ernakulam · Kerala $\cdot$ Liquefaction · Silt

\section{Introduction}

The primary reason for the large earthquakes in India is the movement of the Indian tectonic plate into Asian tectonic plate (initial movement was at high speed of $18-20 \mathrm{~cm}$ year $^{-1}$ before the collision with Eurasian tectonic plate and at a reduced speed of 2-4 $\mathrm{cm}$ year ${ }^{-1}$ afterward [1]). The other reason may be the accumulation of seismic energy in the peninsular region of India [2]. Geographical statistics of India show that almost $54 \%$ of the land is vulnerable to earthquakes. The earthquake zoning map of India [given in the earthquake resistant design code of India-IS 1893 (Part 1-2002)] divides India into four seismic zones (Zone 2, 3, 4 and 5). Previously it consisted of five zones. Zone 5 exhibits the highest level of seismicity, whereas Zone 2 is associated with the lowest level of seismicity. The present study area, Ernakulam - the central part of Kerala-lies in Zone 3.

Ernakulam is called as the commercial capital of the state of Kerala. The Kerala High Court, the Cochin Stock Exchange, many educational institutions and business firms are situated here. The geotechnical characteristics and probable natural hazards of the Ernakulam region are shown in Fig. 1. Because of the lineaments and faults present in this region, the chance of a seismic event is high.

Liquefaction, which is one of the seismic hazards, is responsible for tremendous amounts of damage all over the world. When the saturated soil mass is subjected to seismic or dynamic loads, there is an abrupt build-up of pore water pressure within a short duration. If the soil cannot dissipate the excess pore water pressure, it leads to a reduction in effective shear strength of soil mass. In this state, the soil mass behaves like a liquid and causes huge deformations, settlements, flow failures, etc. This phenomenon is called soil liquefaction. Liquefaction effects on damages of structures are commonly observed in lowlying areas near the water bodies such as rivers, lakes, and oceans. Ernakulam region is highly prone to earthquakes, and therefore, identification and mitigation of liquefaction are essential for this region. In this paper, the liquefaction susceptibility of Ernakulam region has been elaborated.

M. Akhila, akhila144@gmail.com | 'Department of Civil Engineering, National Institute of Technology, Calicut, Kerala, India.

SN Applied Sciences (2019) 1:583 | https://doi.org/10.1007/s42452-019-0576-3 
Fig. 1 Geotechnical characteristics of Ernakulam region (Source: District survey report of minor minerals - Ernakulam District, prepared by Dept. of mining and Geology, Govt. of Kerala)

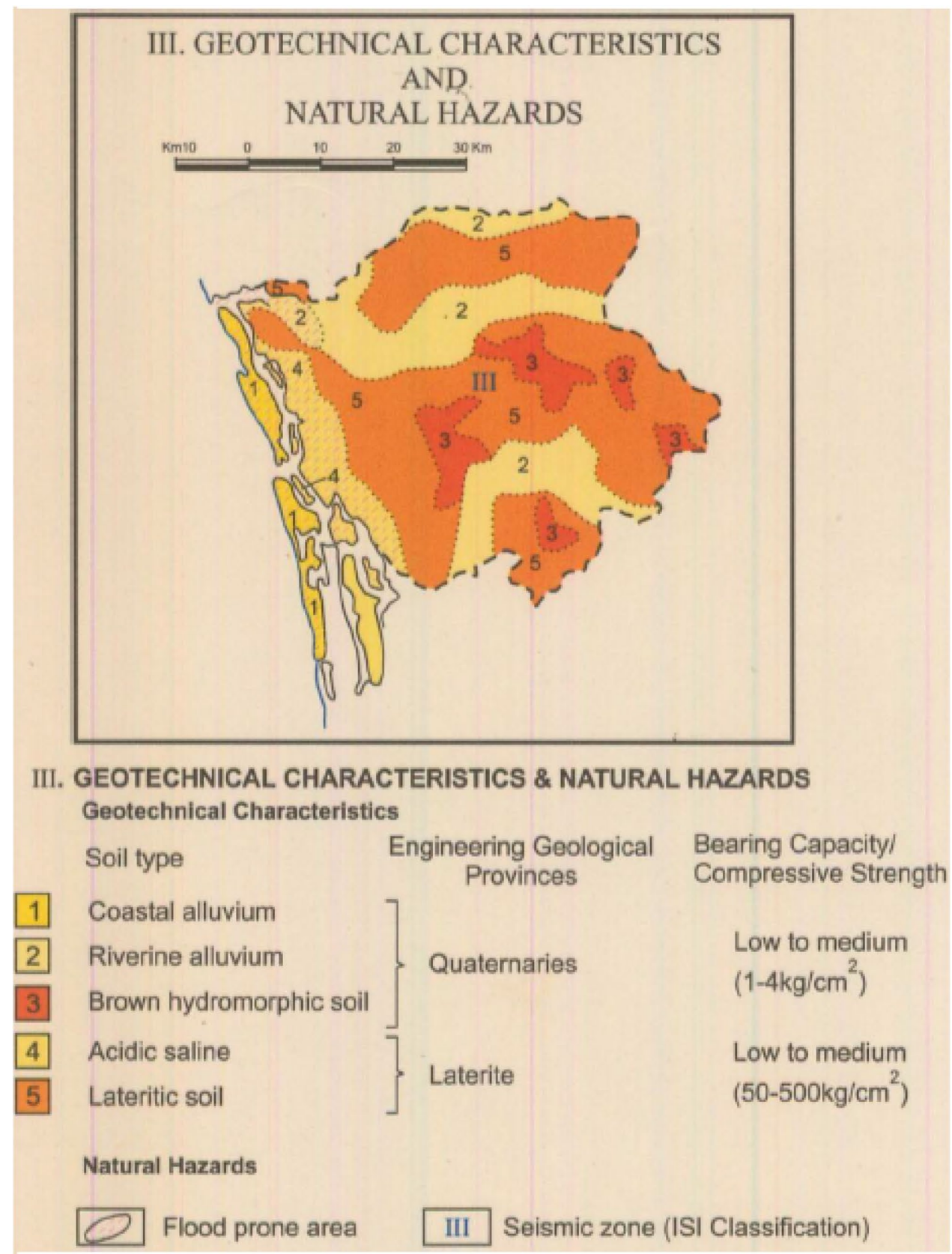

\section{Literature review}

A detailed review has been carried out to analyze the seismicity of Kerala and also to familiarize with the various methods for evaluating liquefaction potential.

\subsection{Seismicity of Kerala}

Kerala lies in Zone 3 of seismic zones in India, which is classified as Moderate Damage Risk Zone which is liable to MSK VII (Medvedev-Sponheuer-Karnik scale) and Ernakulam is ranked as 7 out of the top 10 earthquakeprone areas in India (source: https://www.linkedin.com/ pulse/top-10-earthquake-prone-areas-india-bookandgo/). On 12 December 2000, an earthquake with a local magnitude of 5 was felt strongly in the central part of Kerala (source: http://asc-india.org/lib/20001212-keral a.htm).

Nair [3] carried out extensive studies on the geomorphology and Quaternary geology of the coastal areas of Kerala. Other researchers include Erattupuzha and George [4], Pawar et al. [5], Mathai and Nair [6], Rajendran et al. 
[7], Kunte [8]. The study by Ganesha Raj et al. [9] shows that there are 41 medium/major lineaments in Kerala with length more than $20 \mathrm{~km}$. According to Rajendran et al. [10], the central Midland must be considered as the most seismically potential region in Kerala. Also, the authors suggest that an earthquake of magnitude $\left(M_{\mathrm{L}}\right) 4.5$ to 5.5 can be expected to occur in the central Midland of Kerala every $25 \pm 22$ years.

By comparing many available datasets, a diagram showing the distribution of earthquake events in and around Kerala was prepared by Sreevalsa and Sitharam [11]. Anbazhagan et al. [12] reported that there are many minor lineaments in Kerala and also a probable future earthquake zone in the vicinity of the central region. They reported that an intensity of 6.5 is expected due to probable source zone, with a maximum magnitude $\left(M_{\mathrm{w}}\right)$ of 6.0 (the maximum is expected to occur in central Kerala). The studies done by Biju et al. [13] conclude that "the earthquakes in central Kerala region exhibit a spatial association with NW-SE trending Periyar lineament/fault."

The literature gives a clear idea about the seismicity of Kerala and especially the central region. The occurrence of an earthquake may lead to seismic hazards. The important seismic hazards listed by Kramer [14] are ground shaking, structural hazards, liquefaction, landslides, retaining structure failures, lifeline hazards, tsunami and seiche. Out of all these, liquefaction is one of the most important and complex topics in the field of earthquake geotechnical engineering. Liquefaction is defined as the "transformation of granular material from a solid to a liquefied state as a consequence of increased pore water pressure and reduced effective stress" [15]. Until recently, liquefaction-related studies concentrated on clean sands with the assumption that only sands are susceptible to liquefaction. However, a few earthquakes like the 1976 Tangshan earthquake, the 1989 Loma Prieta earthquake, the 1999 Kocaeli earthquake, the 2010 Chile earthquake, and the 2011 Christchurch earthquake, etc. showed that sand with considerable amount of fines could also liquefy. The investigations about the liquefaction can be done mainly in four ways: field investigations, laboratory investigations, modelling (physical and numerical) and analysis using any commercially available software. A brief review of these methods is presented in the following section.

\subsection{Evaluation of liquefaction potential}

A detailed list of various methods for the evaluation of liquefaction potential is listed in Table 1. Tolon [16] listed several software available for the analysis of liquefaction which is given in Table 2 .

Table 2 Lists of software for liquefaction analysis [16]

\begin{tabular}{llll}
\hline 1D analysis & & 2D analysis & 3D analysis \\
\hline Shake2000 & Apollo & Versat-2D & DYNAFLOW \\
LASS-II & LiqIT & Swandyne & FEQDrain \\
CUMLiq & Peysanj & & Diana \\
CPTInt & SoilGeophysical & & Flac 3D \\
Liquiter & SPTLiq & \\
CLiq & LiquefyPro & & \\
CPTLiq & Geostress & & \\
LatSpread & CyberQuake & & \\
\hline
\end{tabular}

Table 1 Summary of methods to evaluate the liquefaction potential

\begin{tabular}{lll}
\hline Area & Tests & References \\
\hline Field investigations & SPT & {$[25,26,27,28,29,30,31,32]$} \\
& CPT & {$[33,34,35]$} \\
& Shear wave velocity & {$[36,37,38,39,40,41]$} \\
Laboratory investigations & Cyclic triaxial tests & {$[42,43,44]$} \\
& Large-scale simple shear tests & {$[45]$} \\
& Cyclic torsional cylindrical shear test & {$[46]$} \\
Physical modeling & Cyclic undrained simple shear tests & {$[47,48,49]$} \\
& Cyclic hollow torsional test & {$[50]$} \\
Numerical modeling & Large-scale shaking table tests & {$[51,52,53]$} \\
& Dynamic centrifuge test & {$[54,55]$} \\
& Elasto-plastic models & {$[56,57,58]$} \\
& Lade's model with a double plastic potential & {$[59]$} \\
& Generalized plasticity models & {$[60,61]$}
\end{tabular}




\subsection{Critical assessment of the literature}

The first section of the literature gives an idea about the seismicity of Kerala. Most research has been concentrated on the areas such as Idukki and Palaghat $[10,13,17]$. But studies conducted in the commercial capital area are limited. Hence the authors have selected this area for the study. To study the liquefaction susceptibility, some of the available methods have been listed and discussed in the second part of the literature review. Since the SPT data of the study area were available, the authors have chosen the analysis using NovoLiq. The details about the analysis are given in the methodology section.

\section{Methodology}

Borehole data were collected from 37 locations in Ernakulam district of Kerala state [data courtesy: Engineers Diagnostic Centre (P) Ltd.] and analyzed for liquefaction susceptibility.
The locations of boreholes are shown in Fig. 2. The details of soil types and levels of the ground water table are given in Table 3. SPT-based analysis has been carried out to find the liquefaction susceptibility. The main formulae used for the liquefaction analyses are as follows:

The factor of safety against liquefaction (FS) is given by:

$\mathrm{FS}=\frac{\mathrm{CRR}_{7.5} \mathrm{MSF}}{\mathrm{CSR}}$

where $\mathrm{CRR}_{7.5}=$ cyclic resistance ratio for an earthquake with magnitude 7.5, MSF = magnitude scaling factor, $\mathrm{CSR}=$ cyclic stress ratio.

The cyclic stress ratio, CSR, as proposed by Seed and Idriss [18], is given by

$\operatorname{CSR}=\frac{\tau_{a v}}{\sigma_{v}^{\prime}}=0.65\left(\frac{a_{\max }}{g}\right)\left(\frac{\sigma_{v}}{\sigma_{v}^{\prime}}\right) r_{\mathrm{d}}$

where $a_{\max }=$ maximum horizontal ground surface acceleration $(\mathrm{g}), g=$ gravitational acceleration, $\sigma_{v}=$ total

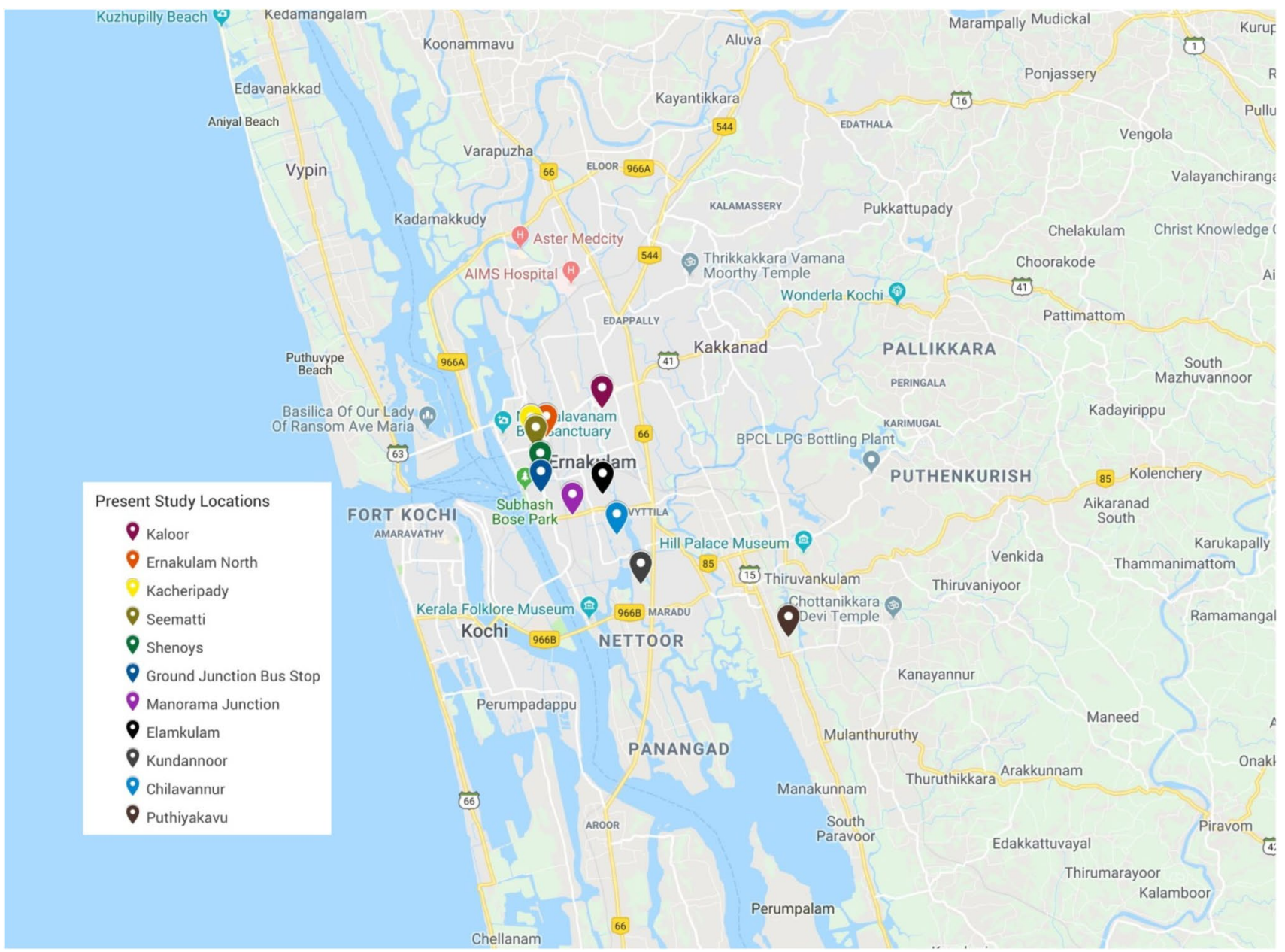

Fig. 2 Location of sites 
Table 3 Details of the areas

\begin{tabular}{|c|c|c|c|c|c|c|c|}
\hline \multirow[t]{2}{*}{ No. } & \multirow[t]{2}{*}{ Area } & \multicolumn{2}{|l|}{ Location } & \multirow{2}{*}{$\begin{array}{l}\text { Number of } \\
\text { boreholes }\end{array}$} & \multirow{2}{*}{$\begin{array}{l}\text { Distance from } \\
\text { the previous } \\
\text { site }\end{array}$} & \multirow[t]{2}{*}{ Major soil type } & \multirow[t]{2}{*}{ GWT (m) } \\
\hline & & Latitude $(\mathrm{N})$ & Longitude (E) & & & & \\
\hline 1 & Kaloor & 9.997 & 76.302 & 3 & - & Silty clayey sand & 1 to 1.8 \\
\hline 2 & Ernakulam North & 9.989 & 76.285 & 2 & $2.8 \mathrm{~km}$ & $\begin{array}{l}\text { Silty sand in top layers; clay from } 6 \mathrm{~m} \\
\text { depth }\end{array}$ & 1 \\
\hline 3 & Kacheripadi & 9.989 & 76.281 & 2 & $1.2 \mathrm{~km}$ & $\begin{array}{l}\text { Silty sand and silty clay; laterite from } 16 \mathrm{~m} \\
\text { depth }\end{array}$ & 0.7 \\
\hline 4 & Seematti Junction & 9.986 & 76.282 & 4 & $750 \mathrm{~m}$ & Fine and clay; laterite at greater depths & 0.4 to 1.5 \\
\hline 5 & Shenoy's & 9.978 & 76.283 & 1 & $850 \mathrm{~m}$ & Laterite clay with sand (but very low N) & 0.5 \\
\hline 6 & Ground Junction & 9.973 & 76.284 & 4 & $700 \mathrm{~m}$ & Clay and silty clay & $<1$ \\
\hline 7 & Manorama Junction & 9.966 & 76.293 & 2 & $2.6 \mathrm{~km}$ & Clay with silt & 1 \\
\hline 8 & Elamkulam & 9.974 & 76.301 & 4 & $1.6 \mathrm{~km}$ & Clay and silt (presence of organic matter) & 0.7 to 1 \\
\hline 9 & Kundanoor & 9.947 & 76.314 & 8 & $5.3 \mathrm{~km}$ & Silty clay; laterite at greater depths & 0 \\
\hline 10 & Chilavannur & 9.963 & 76.306 & 2 & $5 \mathrm{~km}$ & Alternate layers of clay and sand & 0.5 \\
\hline 11 & Puthiyakavu & 9.932 & 76.358 & 5 & $9.8 \mathrm{~km}$ & Sand clay with laterite (dense condition) & $<1$ \\
\hline
\end{tabular}

Table 4 Qualitative assessment of abundance and general character of liquefaction effects as a function of LSI for areas with widespread liquefiable deposits [21]

LSI Abundance and general character of liquefaction effects

5 Very sparsely distributed minor ground effects include sand boils with sand aprons up to $0.5 \mathrm{~m}$ ( $1.5 \mathrm{ft}$ ) in diameter, minor ground fissures with openings up to $0.1 \mathrm{~m}$ wide, ground settlements of up to $25 \mathrm{~mm}$ (1 in.). Effects lie primarily in areas of recent deposition and shallow ground water table such as exposed stream beds, active flood plains, mud flats, shore lines, etc.

30 Generally sparse but locally abundant ground effects include sand boils with aprons up to $2 \mathrm{~m}$ (6 ft) diameter, ground fissures up to

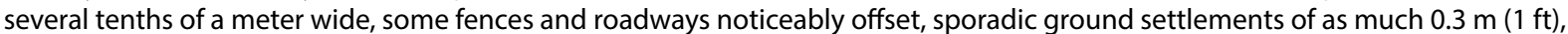

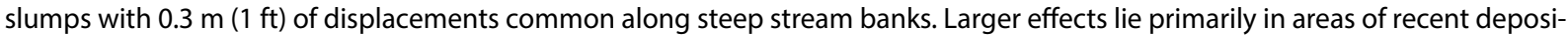
tion with a ground water table less than $3 \mathrm{~m}(10 \mathrm{ft})$ deep

90 Very abundant ground effects include numerous sand boils with large aprons, $30 \%$ or more of some areas covered with freshly deposited sand, many long Assures with multiple strands parallel streams and shore lines with openings as wide as two or more meters, some intact masses of ground between Assures are horizontally displaced a couple of meters down gentle slopes, large slumps are common in stream and other steep banks, ground settlements of more than $0.3 \mathrm{~m}(1 \mathrm{ft})$ are common

Table 5 Relation between vertical settlement and extend of damage [23]

\begin{tabular}{lll}
\hline Settlement $(\mathrm{cm})$ & Extend of damage & $\begin{array}{l}\text { Phenomena on ground } \\
\text { surface }\end{array}$ \\
\hline $0-10$ & Light to no damage & Minor cracks \\
$10-30$ & Medium damage & Small cracks, oozing of sand \\
$30-70$ & Extensive damage & $\begin{array}{l}\text { Large cracks, spouting of } \\
\text { sands, large offsets, lateral } \\
\text { movement }\end{array}$ \\
\hline
\end{tabular}

overburden pressure at depth $z, \sigma_{v}{ }^{\prime}=$ effective overburden pressure at depth $z, r_{\mathrm{d}}=$ stress reduction factor.

Liquefaction analyses were carried out in NovoLiq (Version 2.40.2012.1006) [19]. NovoLiq software is designed for soil liquefaction analysis during the earthquake and supports multi-layer as well as single layer stratigraphy. The software presents the results of the analysis as a factor of safety against soil liquefaction, the probability of soil liquefaction, post-liquefaction site conditions, including ground settlement, lateral movement (spreading), etc.

From the input, i.e., the soil profile details, the NovoLiq calculates the CSR value based on Eq. (2). Then, the CRR values for the present study are calculated using the NCEER Workshop (1997) method. The factor of safety is then calculated using Eq. (1). Other than the factor 


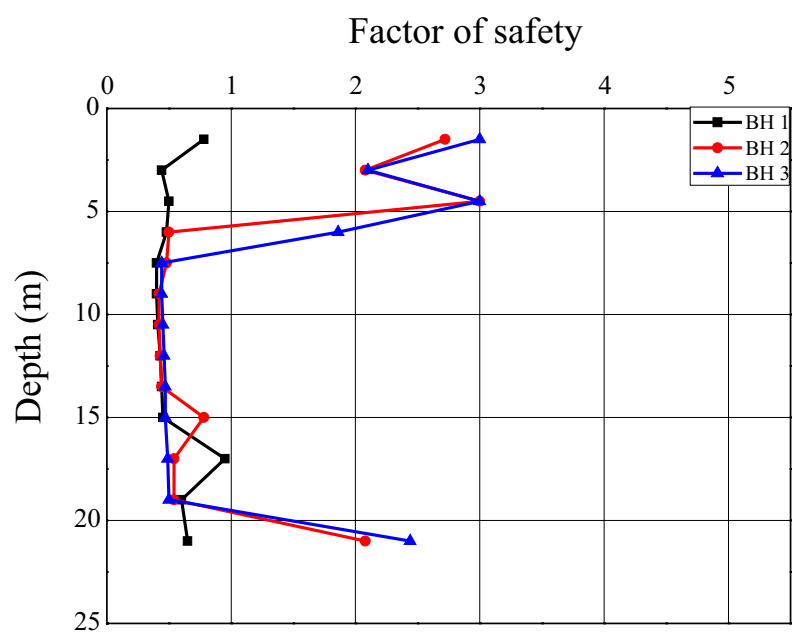

Fig. 3 Depth versus factor of safety against liquefaction-Kaloor

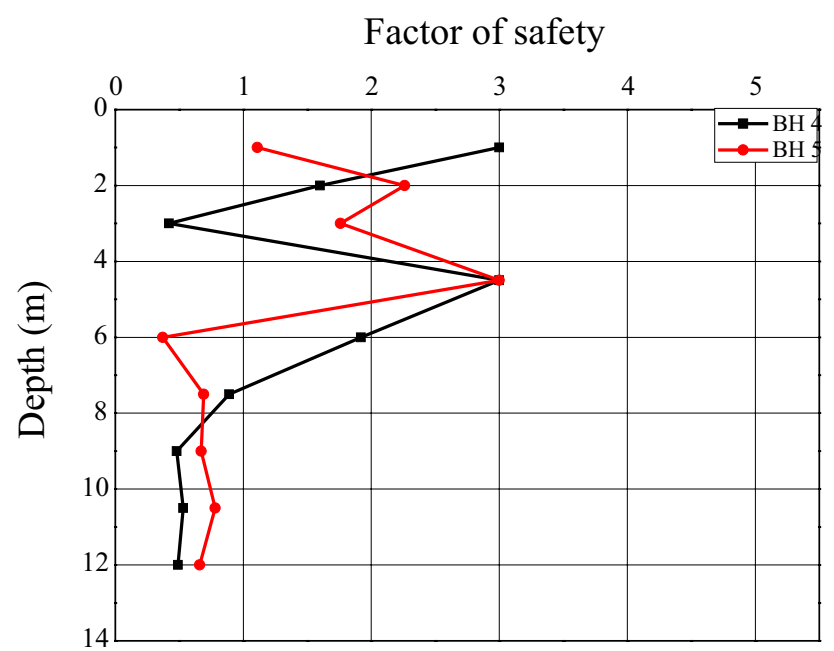

Fig. 4 Depth versus factor of safety against liquefaction-Ernakulam North

of safety against liquefaction, the following are also analyzed:

- The probability of liquefaction [20]: It is calculated based on the probabilistic triggering correlation for clean sands for $M=7.5$.

- Liquefaction severity index [21]: LSI, a measure of ground failure displacement, is based on the displacement of lateral spreads. LSI is useful for determining the relative liquefaction hazard and provide an index of possible maximum ground displacement. The general range of $\mathrm{LSI}$ values and its corresponding liquefaction effects are given in Table 4.
Factor of safety

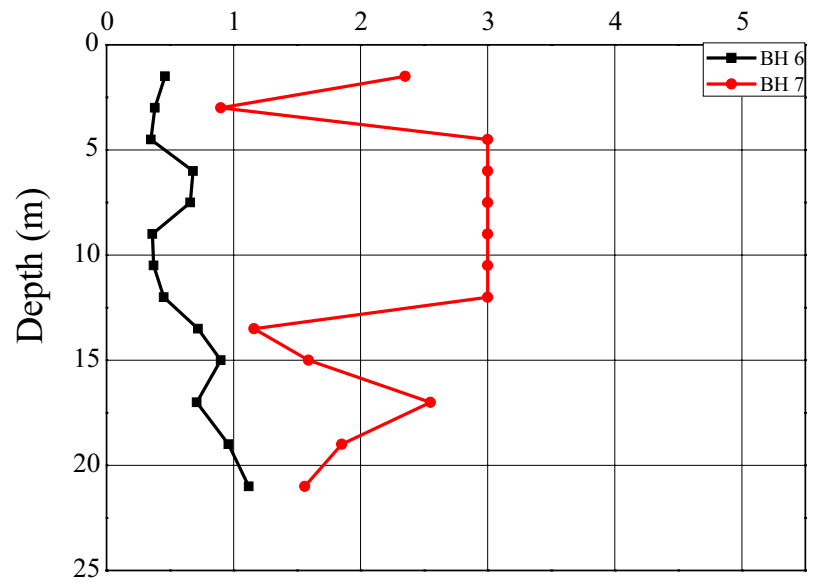

Fig. 5 Depth versus factor of safety against liquefaction-Kacheripadi

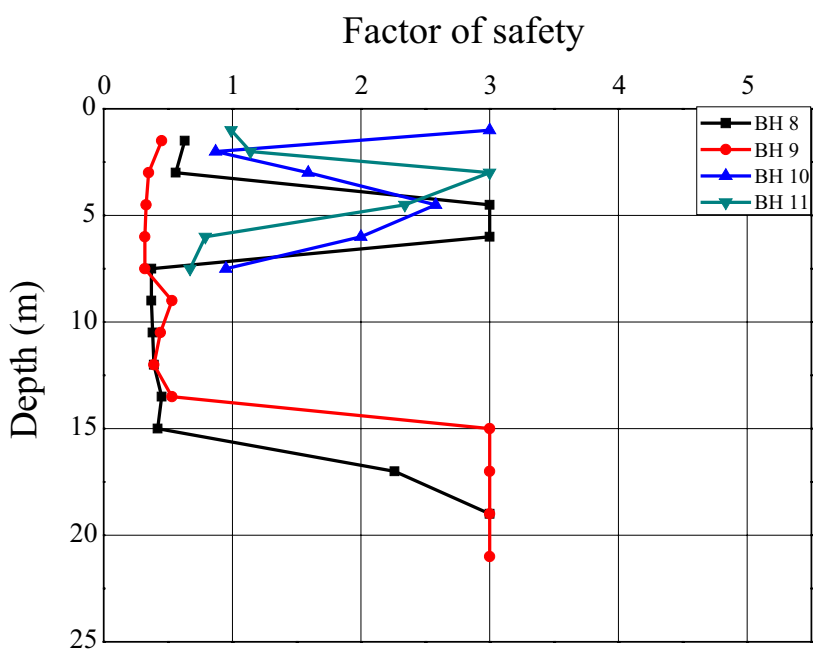

Fig. 6 Depth versus factor of safety against liquefaction-Seematti junction

- Lateral spreading [22]: the method proposed by Zhang et al. [22] (which was developed using case history) is quite simple and can be applied with only a few additional calculations following SPT- or CPT-based liquefaction-potential analysis.

- Vertical settlement [23]: the extent of damage corresponding to the settlement is proposed by Ishihara and Yoshimine [23] based on the case histories. The range and corresponding description are given in Table 5.

Results are discussed in the following section. 
Factor of safety

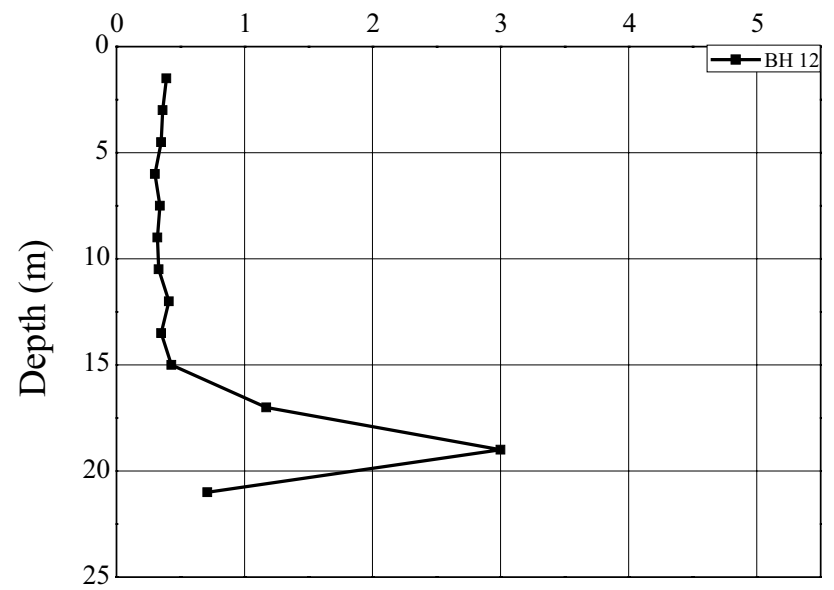

Fig. 7 Depth versus factor of safety against liquefaction-Shenoy's

Factor of safety

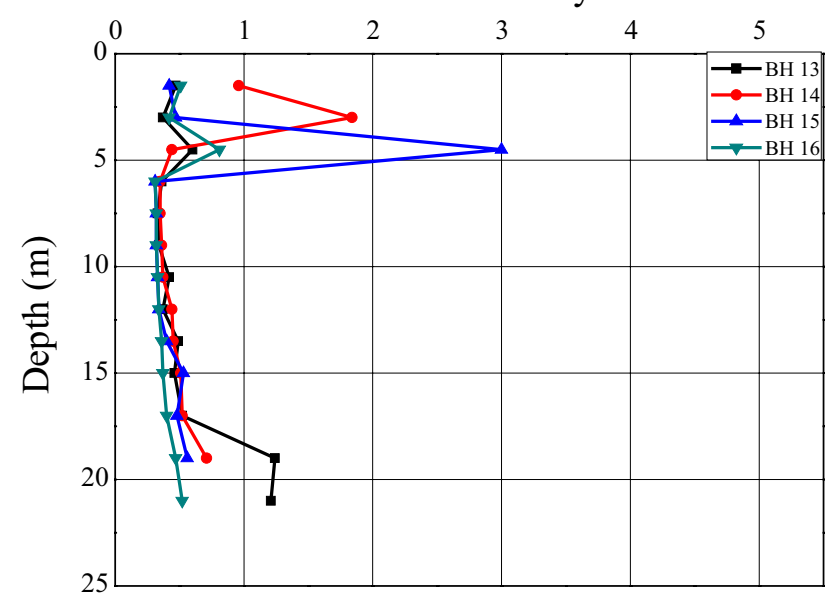

Fig. 8 Depth versus factor of safety against liquefaction-Ground junction

\section{Results and discussion}

Liquefaction analyses have been done on 37 borehole data for a PGA of $0.2 \mathrm{~g}$ and an earthquake magnitude of 6 (the ground water table is varied for each location as per the real site data). The depth versus factor of safety against liquefaction graphs of all regions is shown in Figs. 3, 4, 5, $6,7,8,9,10,11,12,13$ and 14 . The results are briefed in Tables 6 and 7 by differentiating the depth of each borehole into "prone to liquefaction" and "safe against liquefaction." It can be seen that the majority of the sites are prone to liquefaction. (i.e., factor of safety against liquefaction is less than one). Various maps have been prepared which shows the factor of safety against liquefaction at $1.5 \mathrm{~m}$ depth, $7.5 \mathrm{~m}$ depth, an average factor of safety (average

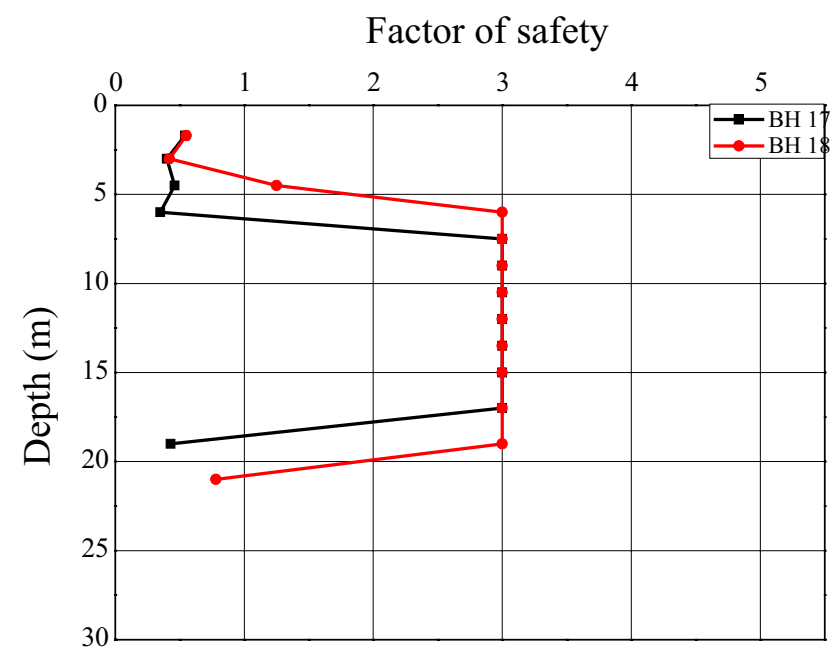

Fig. 9 Depth versus factor of safety against liquefaction-Manorama junction

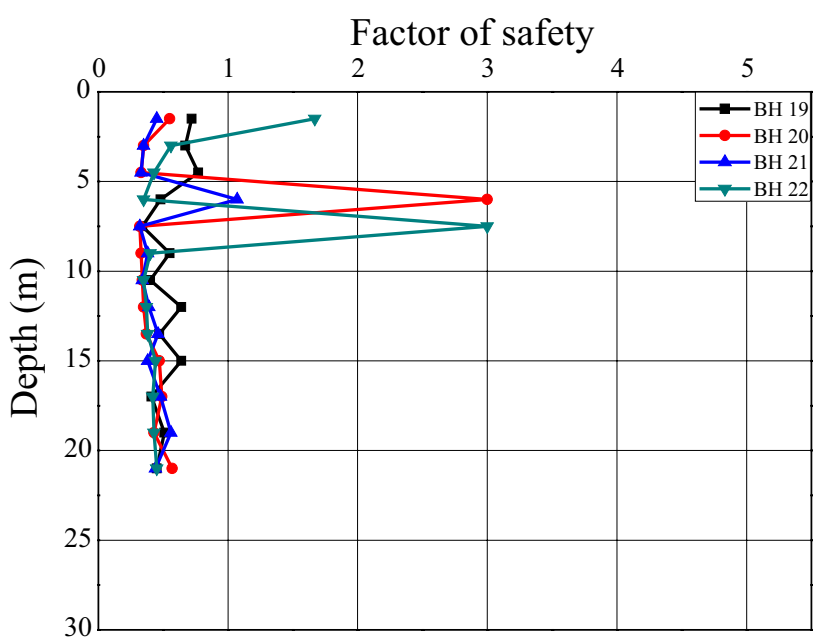

Fig. 10 Depth versus factor of safety against liquefaction-Elamkulam

factor of safety of all considered depths) and the average of the 10 analyses carried out at a particular borehole (Figs. 15, 16, 17, 18).

Also, maps which show the probability of liquefaction, lateral spreading, and vertical settlement are also included (Figs. 19, 20, 21). The numerical values of the same are given in Table 8. The liquefaction severity index for all locations (for an earthquake of magnitude 6 and PGA $0.2 \mathrm{~g}$ ) was found to be 3 (refer $L S I=5$ in Table 4). The probability of liquefaction (PL) is more than $50 \%$ for 24 boreholes considered and less than 10\% for 3 boreholes. The high values of $\mathrm{PL}$ are in Chilavannur and Kundannur regions and least values correspond to the Puthiyakavu region. The lateral spreading and vertical displacement are higher 


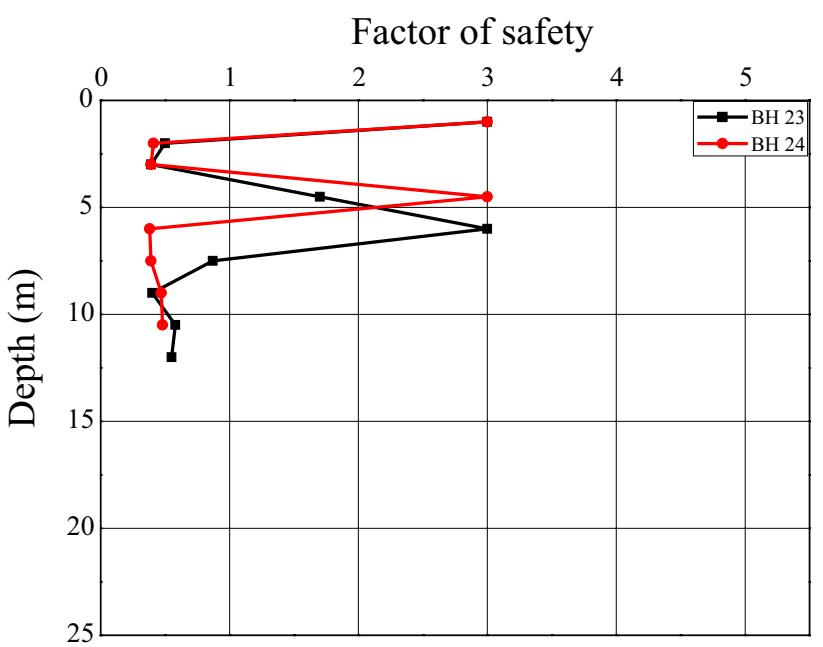

Fig. 11 Depth versus factor of safety against liquefaction-Chilavnnur

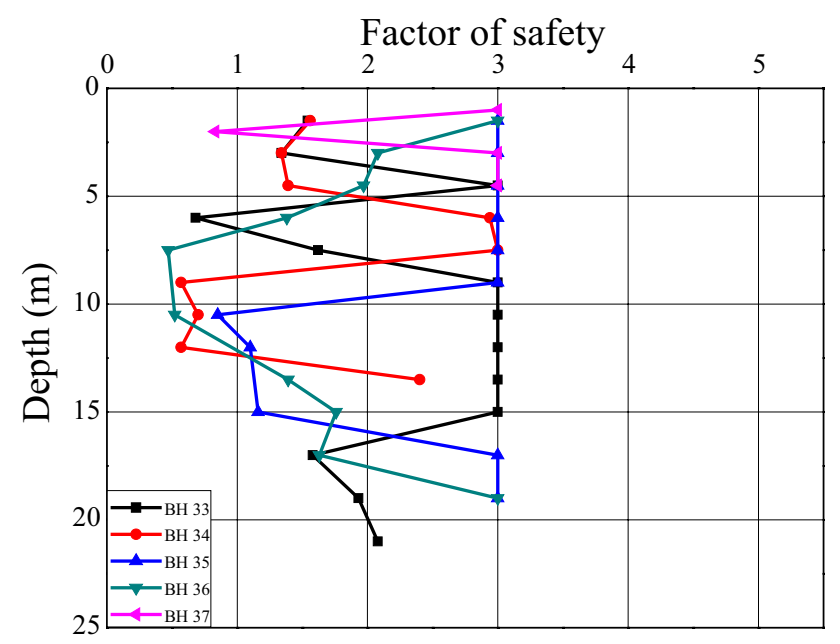

Fig. 12 Depth versus factor of safety against liquefaction-Puthiyakavu

for Kundannur area and least for Puthiyakavu. In Kundannur area, the values of lateral spreading are gone up to $168 \mathrm{~cm}$ and the vertical settlement up to $39 \mathrm{~cm}$, whereas in Puthiyakavu area, both the lateral spreading and the vertical settlement are in the range of $0-2 \mathrm{~cm}$ only.

\section{Region wise analyses}

In the Kaloor area, only the top layers (BH 2 and 3) are safe against liquefaction (Fig. 3). These layers consist of fine gravels which give an SPT N value greater than 10 . All other soil layers of Kaloor region have SPT N less than

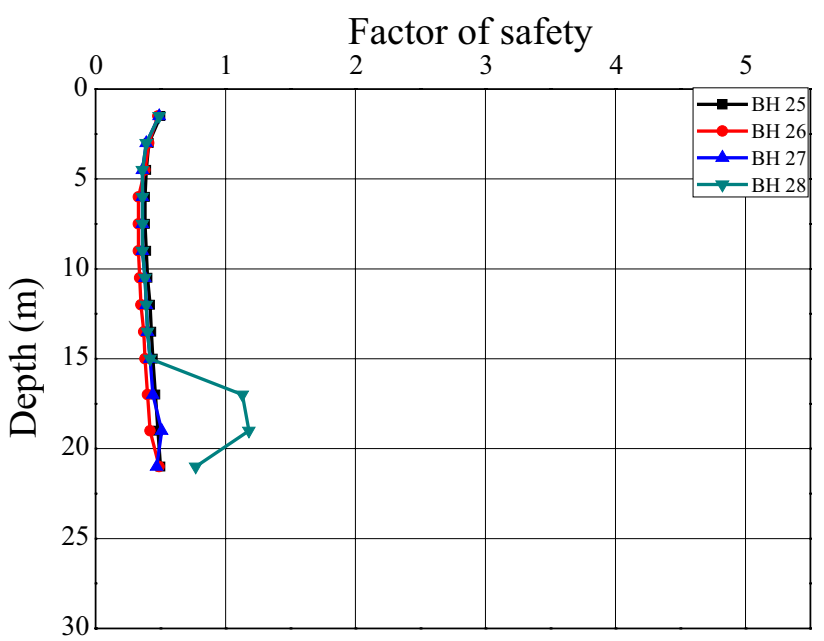

Fig. 13 Depth versus factor of safety against liquefactionKundannur 1

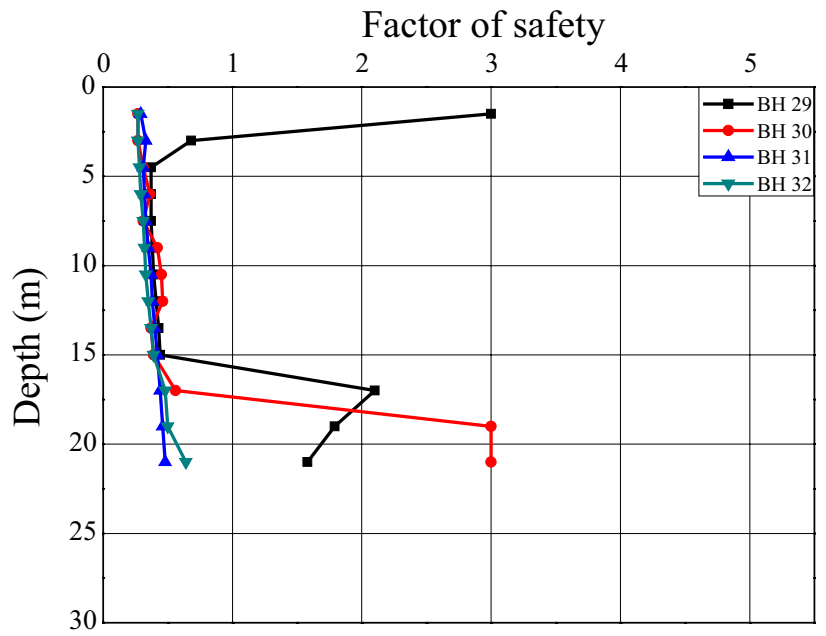

Fig. 14 Depth versus factor of safety against liquefactionKundannur 2

5. The average probability of liquefaction is greater than $50 \%$ in all the 3 boreholes. Similar results are obtained for the Ernakulam North region (Fig. 4) also. There, the top layers consist of sand with SPT N $>10$. But the deeper layers are of silt and clay with SPT $\mathrm{N}<5$. According to Peck et al. [24], when SPT $N$ values are between 0 and 4, the soil state is very loose and when SPT N is 5 and 10 , the soil state is loose. Both soils show high susceptibility to liquefaction. However, the probability of liquefaction is around $38 \%$ only.

In Kacheripadi, the selected soil profiles of 2 boreholes are in two entirely different states. In one, all the layers have soils with SPT N less than 5; but in the other, the soils 
Table 6 Results in a nutshell (19 boreholes)

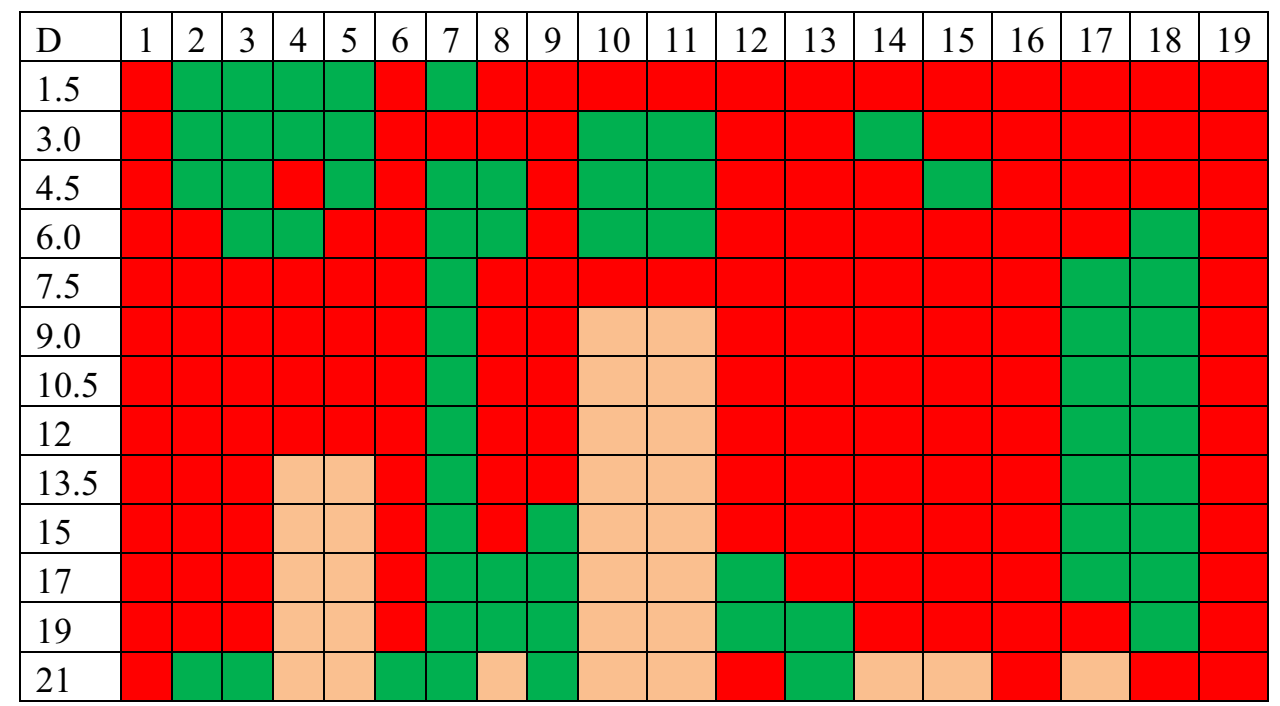

Table 7 Results in a nutshell (remaining 18 boreholes)

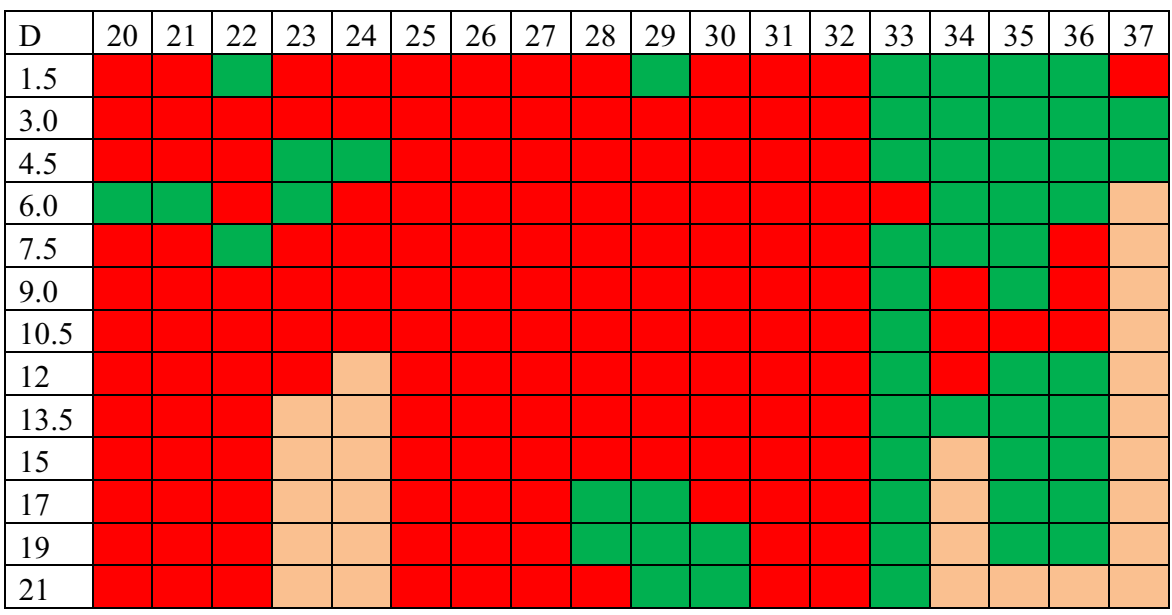

Note:

\begin{tabular}{cl}
\multicolumn{2}{c}{ Number and areas } \\
1-3 & Kaloor \\
$4-5$ & Ernakulam North \\
$6-7$ & Kacheripadi \\
$8-11$ & Seematti Junction \\
12 & Shenoy's
\end{tabular}

13-16 Ground Junction

17-18 Manorama Junction

19-22 Elamkulam

23-24 Chilavannur

25-32 Kundanoor

33-37 Puthiyakavu (mainly sand and silt) are in very dense condition which gives high SPT N value. The results of the liquefaction analysis are given in Fig. 5. From Fig. 5, it is clear that one area is completely prone to liquefaction while the other is safe against liquefaction. Probability of liquefaction and settlements are higher for $\mathrm{BH} 6$ and least for $\mathrm{BH}$ 7. This is the best example which shows how significant variations 


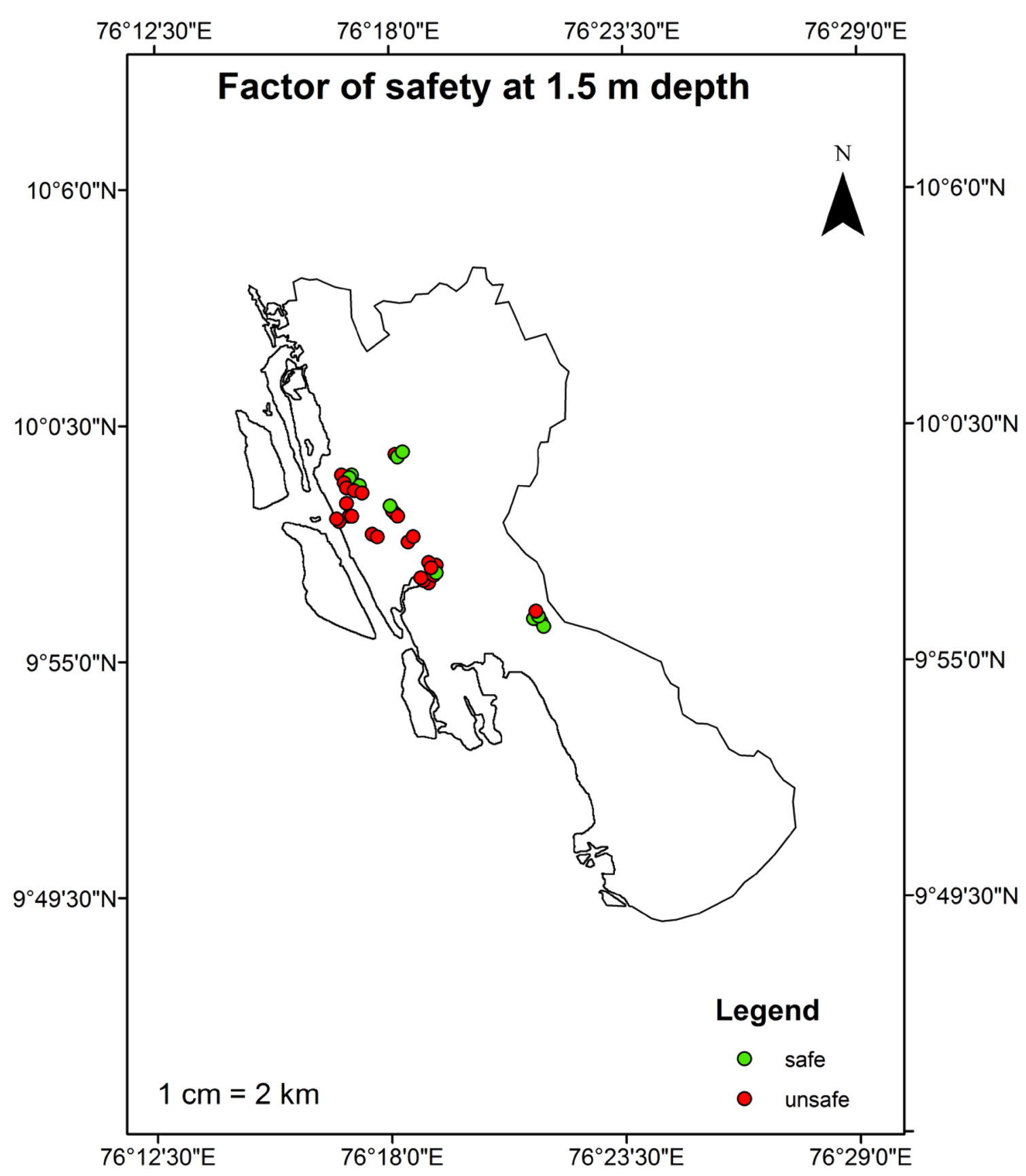

Fig. 15 Liquefaction susceptibility map showing the factor of safety at $1.5 \mathrm{~m}$ depth

in liquefaction susceptibility are possible within a short span of distance due to variations in the soil profile.

The soils near Seematti Junction consist of lateritic soils in some layers. Hence these layers offer a high factor of safety against liquefaction in this region (Fig. 6). The probability of liquefaction is less than $20 \%$ and the settlements are less than $3 \mathrm{~cm}$. The soil profile of Shenoy's Junction consists of clayey soils (clay content more than 50\%) up to a depth of $19 \mathrm{~m}$ below which the presence of laterite is seen. Hence the top layers are prone to liquefaction (Fig. 7). The probability of liquefaction is around $67 \%$ and lateral spreading is more than $100 \mathrm{~cm}$. 


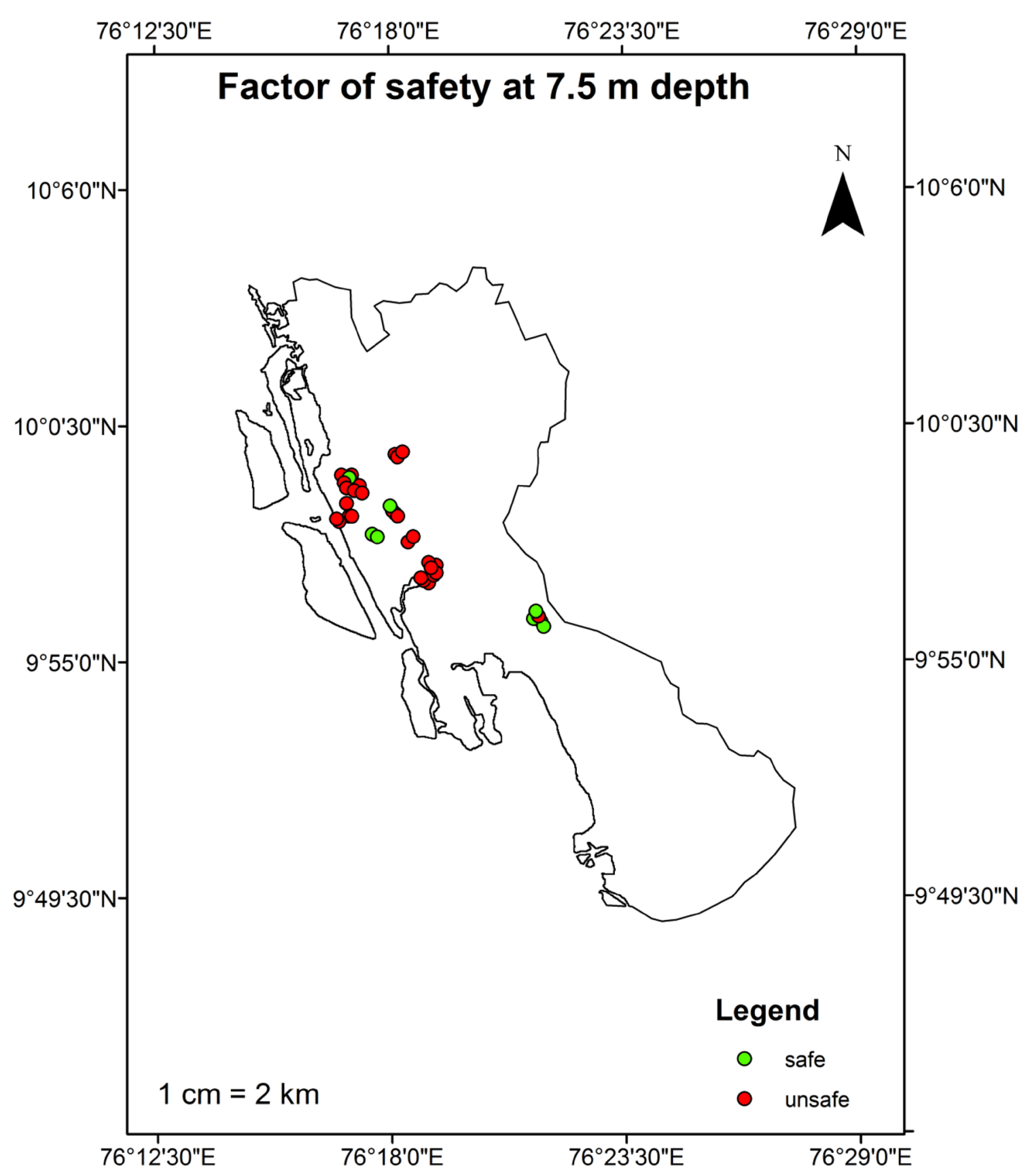

Fig. 16 Liquefaction susceptibility map showing the factor of safety at $7.5 \mathrm{~m}$ depth

In Ground Junction area, the major soil type is clay with SPT N less than 5 in most of the layers (with the presence of silt in top layers). The probability of liquefaction is greater than $60 \%$ and the settlements are in the order of $50-75 \mathrm{~cm}$. Therefore, this area also is highly prone to liquefaction (Fig. 8). But near Manorama Junction, even from a depth of $4.5 \mathrm{~m}$, the SPT N values are greater than 10. So only the top layers are susceptible to liquefaction (Fig. 9). This region is very safe compared to all other 


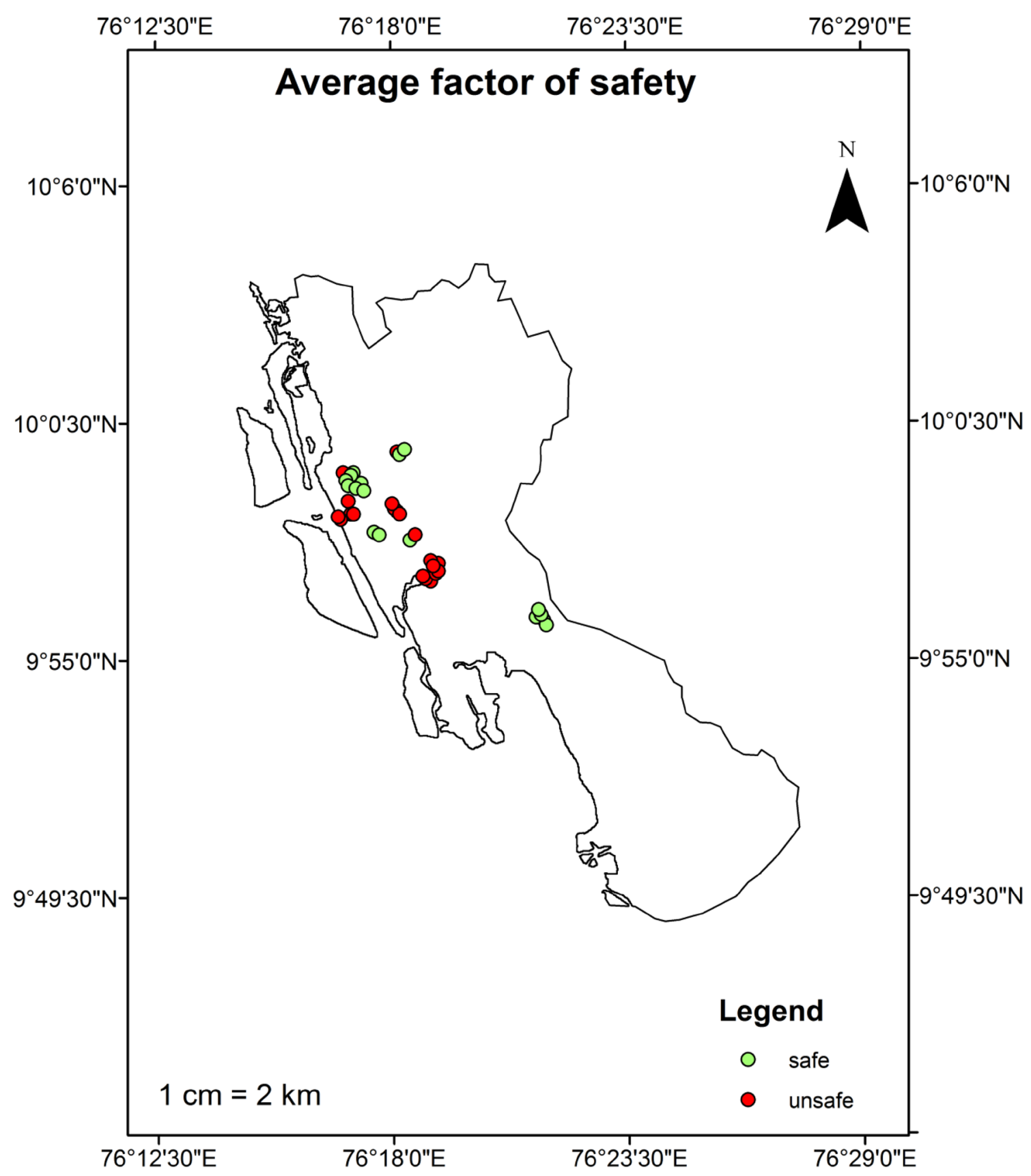

Fig. 17 Liquefaction susceptibility map showing the average factor of safety

regions discussed so far. The probability of liquefaction is less than $30 \%$ and settlements are less than $10 \mathrm{~cm}$ only.

Elamkulam region shows the presence of organic matter in some soil layers. It may be due to the sewage treatment plant located in this area. The results shown in Fig. 10 depict that Elamkulam region is highly prone to liquefaction under the current analyses parameters. In all locations, the probability of liquefaction is more than $65 \%$. In Chilavannur, some of the soil layers consist of dense sand which offers resistance against the liquefaction (Fig. 11). The SPT tests terminate around 10-12 $\mathrm{m}$ depth because of the hard strata consisting of stiff clay. Even then 


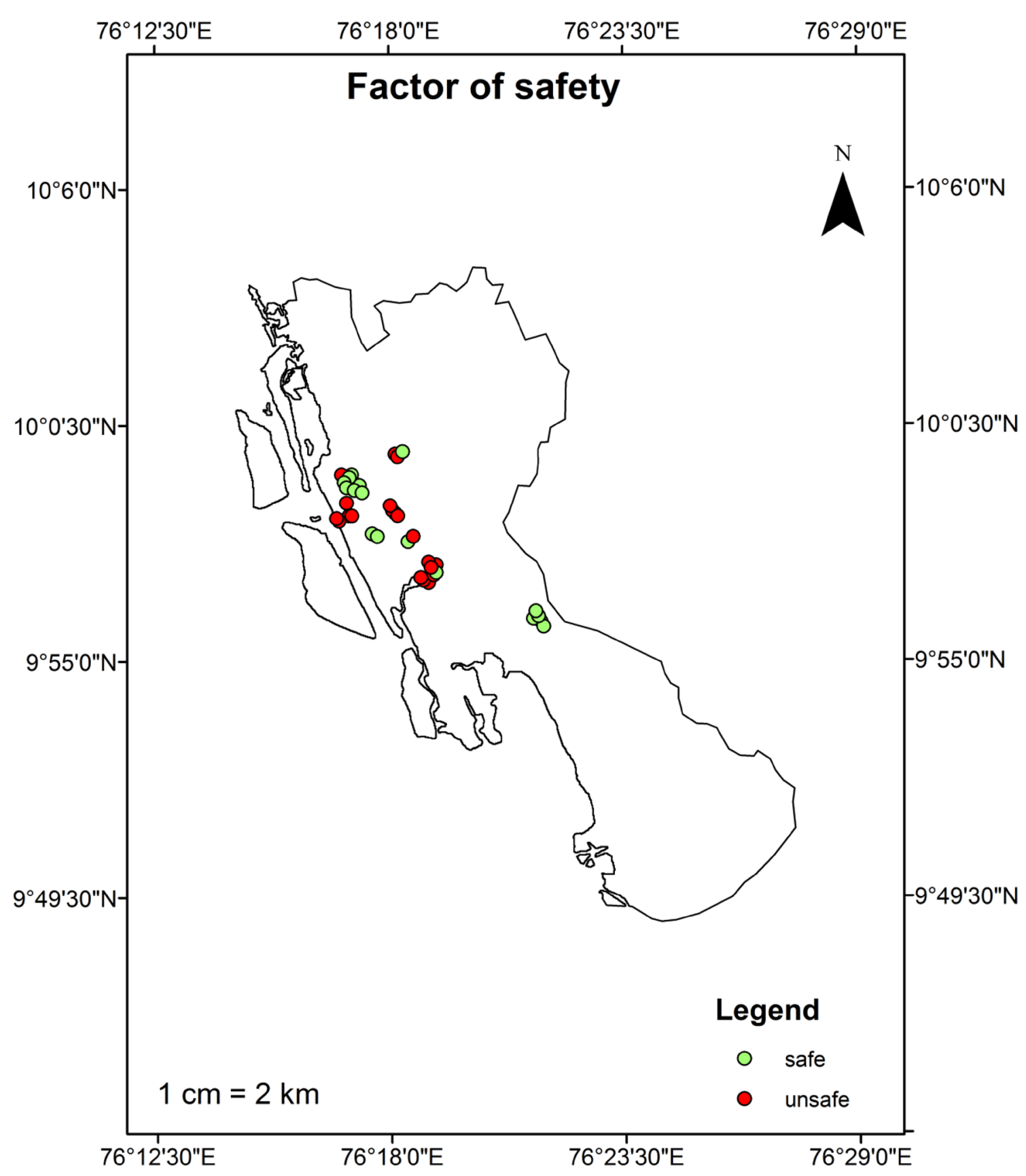

Fig. 18 Liquefaction susceptibility map showing the factor of safety

the average probability of liquefaction is very high (more than $80 \%$ ). Puthiyakavu, which is situated about three $\mathrm{km}$ from Tripunitara, is comparatively safer against liquefaction (Fig. 12). In all the 5 locations, probability of liquefaction is less than $25 \%$ and most of the settlements are in the range of $1-2 \mathrm{~cm}$ only. This is due to the high SPT $N$ values offered by the stiff soil layers.

Kundannur is a highly developing area of Ernakulam city. It is at the junction of three National Highways, namely NH 47, NH 49 and NH 47A. The Le Meridien and Crown Plaza hotels are situated near Kundannur 


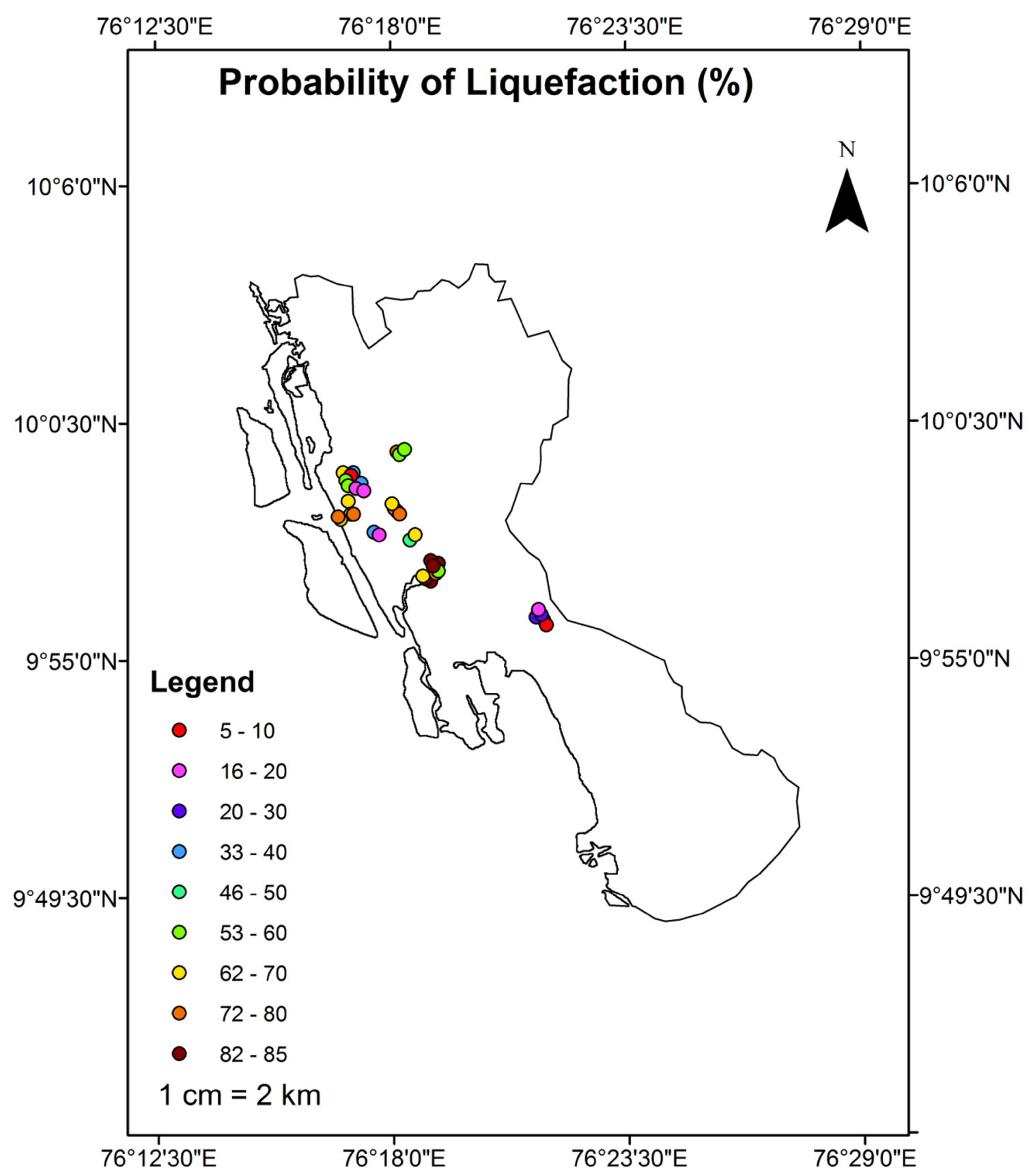

Fig. 19 Map showing the probability of liquefaction of the selected region

junction. Many shopping malls are proposed and under construction in Kundannur. Many automobile companies including Audi, Volkswagen, BMW, etc. have their showrooms in this area which shows the socio-economic importance of Kundannur. Major soil type is silty clay. Laterite is found in greater depth. From the analysis of the data collected from eight boreholes, it is clear that this region is highly susceptible to liquefaction (Figs. 13, 14). In most of the locations, the probability of liquefaction is around $80 \%$. The lateral spreading is gone up to $168 \mathrm{~cm}$ and maximum value of vertical settlement is around $40 \mathrm{~cm}$. The main reason may be the ground water table which is at ground level itself.

In short, Manorama Junction, Puthiyakavu and some areas near Kacheripadi are safe against liquefaction as per the analysis. All others are prone to liquefaction if 


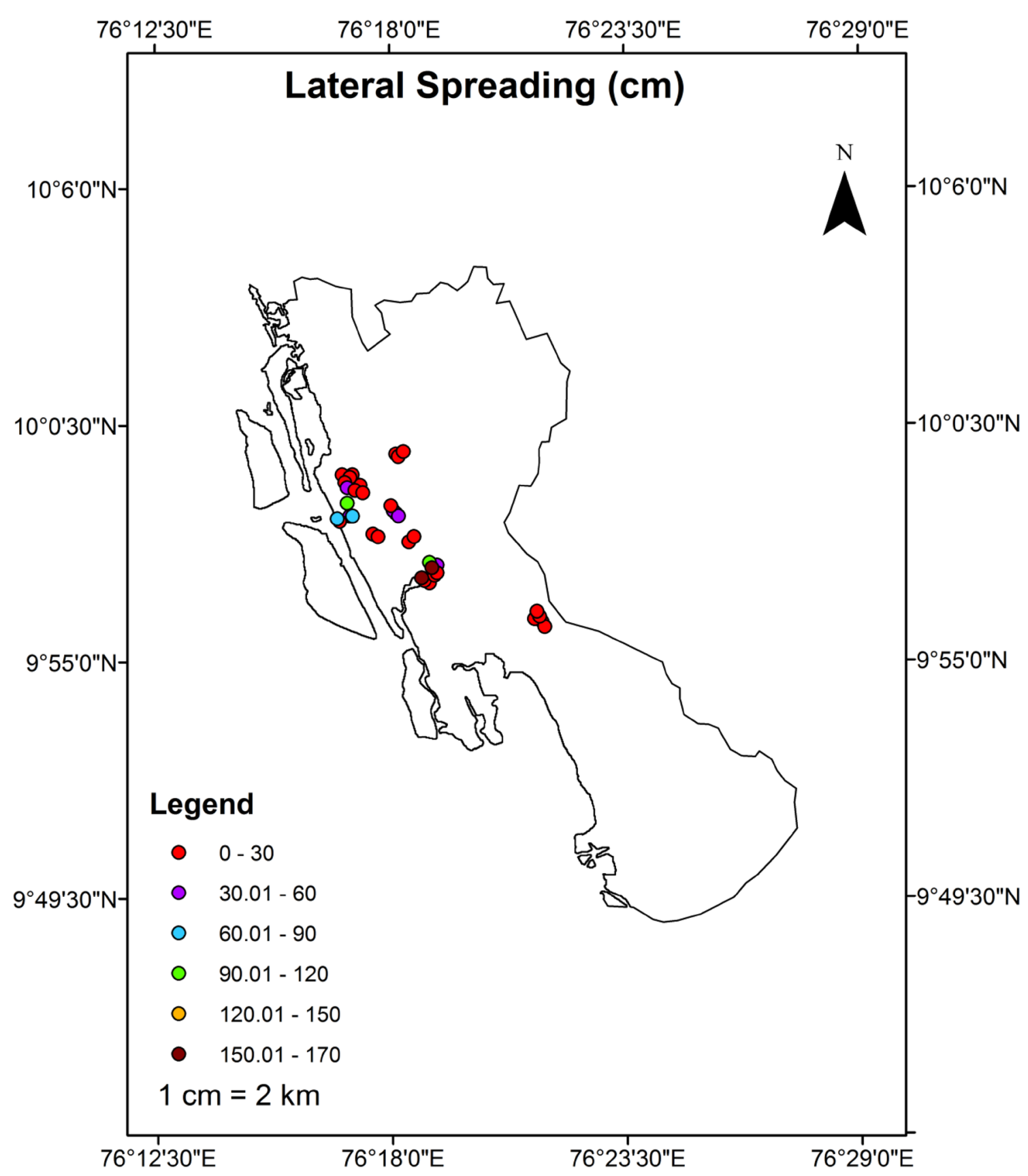

Fig. 20 Map showing the lateral spreading of the selected region

an earthquake with a PGA of $0.2 \mathrm{~g}$ and a magnitude of 6 hits the areas.

The obtained values of the factor of safeties can be used to find the factor of safety against liquefaction for an earthquake with other $a_{\max }$ and earthquake magnitude. To find the factor of safety for any other earthquake with different $a_{\max }$ multiply by the ratio of $0.2 / a_{\max }$ (the earthquake magnitude remaining the same). Similarly to find the factor of safety for any other earthquake magnitude, multiply by the ratio of MSF of that earthquake magnitude/1.76 (1.76 is the MSF given by Idriss for a magnitude of 6 ). 


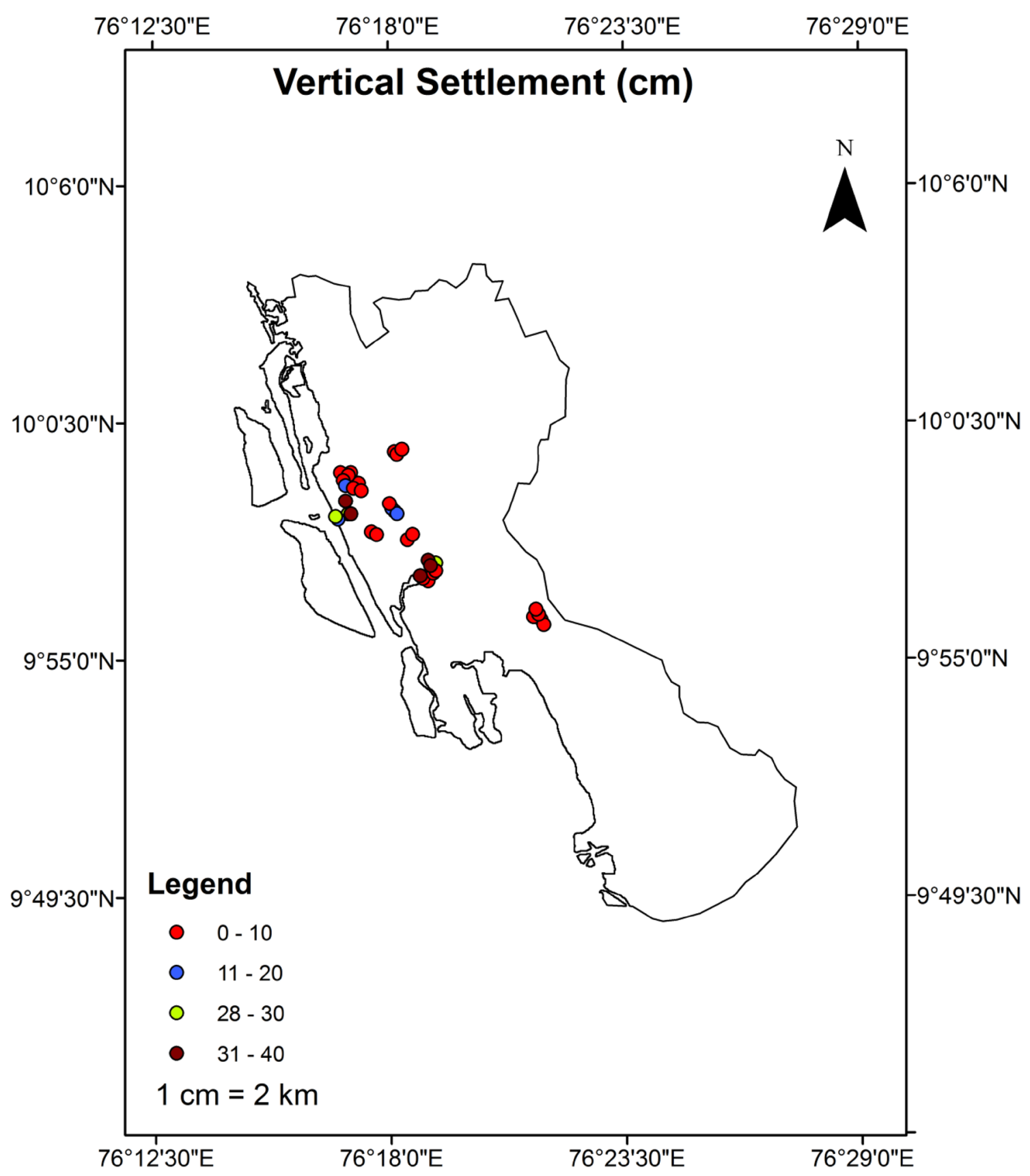

Fig. 21 Map showing the vertical settlement of the selected region

\section{Effect of various parameters on liquefaction susceptibility}

To find the effect of PGA, earthquake magnitude and ground water table on the liquefaction susceptibility, the
PGA is varied from 0.2 to $0.5 \mathrm{~g}$; the earthquake magnitude is varied between 5 and 8 , and the ground water table is varied as $0, x, 2 x$ and $3 x$ ( $x=$ original ground water table at the particular location). A total of 10 liquefaction analyses has been performed for each borehole data. 
Table 8 Results of liquefaction analysis

\begin{tabular}{lcrrlrrr}
\hline BH No & PL $(\%)$ & LS $(\mathrm{cm})$ & VS $(\mathrm{cm})$ & BH no. & PL $(\%)$ & LS (cm) & VS (cm) \\
\hline 1 & 72.76 & 11 & 6 & 20 & 73.14 & 38 & 19 \\
2 & 55.02 & 10 & 6 & 21 & 74.65 & 37 & 19 \\
3 & 57.51 & 5 & 3 & 22 & 68.66 & 17 & 10 \\
4 & 38.67 & 10 & 6 & 23 & 83.92 & 11 & 7 \\
5 & 37.40 & 5 & 2 & 24 & 82.11 & 48 & 28 \\
6 & 62.37 & 14 & 8 & 25 & 83.09 & 16 & 9 \\
7 & 4.76 & 1 & 0 & 26 & 74.61 & 12 & 7 \\
8 & 53.07 & 8 & 5 & 27 & 57.75 & 9 & 5 \\
9 & 53.62 & 40 & 19 & 28 & 65.90 & 156 & 33 \\
10 & 15.8 & 1 & 0 & 29 & 83.21 & 102 & 31 \\
11 & 19.98 & 3 & 2 & 30 & 81.72 & 168 & 39 \\
12 & 67.12 & 104 & 34 & 31 & 46.07 & 8 & 4 \\
13 & 66.83 & 59 & 30 & 32 & 62.1 & 5 & 3 \\
14 & 64.83 & 20 & 11 & 33 & 7.88 & 1 & 0 \\
15 & 71.92 & 66 & 28 & 34 & 26.35 & 2 & 3 \\
16 & 75.44 & 75 & 31 & 35 & 7.68 & 1 & 1 \\
17 & 33.28 & 10 & 6 & 36 & 20.46 & 5 & 3 \\
18 & 18.05 & 1 & 1 & 37 & 16.63 & 0 & 0 \\
19 & 66.42 & 18 & 10 & & & & \\
\hline
\end{tabular}

$P L$ probability of liquefaction, $L S$ lateral spreading, VS vertical settlement
When the PGA increased from 0.2 to $0.3 \mathrm{~g}, 0.4 \mathrm{~g}$ and $0.5 \mathrm{~g}$, the factor of safety decreased approximately by $33 \%$, $50 \%$ and $60 \%$, respectively (all other factors, i.e., the earthquake magnitude, ground water table, soil properties, etc., being the same). When the earthquake magnitude decreased to 5 from 6 , the factor of safety was increased by nearly $20-25 \%$. When the earthquake magnitude is raised from 6 to 7 and 8 , the factor of safeties decreased by $31 \%$ and $52 \%$, respectively. Figures 22,23 and 24 illustrate the results of $\mathrm{BH} 1$ of Kaloor, $\mathrm{BH} 19$ of Elamkulam and $\mathrm{BH} 33$ of Puthiyakavu, respectively.

The effect of the ground water table is site-specific. When the ground water table is raised to ground level from $x$, the factor of safety decreased considerably. For, e.g., in the case of $\mathrm{BH} 1$ of Kaloor ( $x=1 \mathrm{~m}$ in this particular $\mathrm{BH}$ ), the factor of safety decreased by $5-6 \%$ in top soil layers, but around $20 \%$ decrease was observed in intermediate soil layers. When the ground water table was lowered to $2 x$ and $3 x$, factor of safety doubles near the ground surface. In the other layers, an increase between 5 to $10 \%$ was observed. In the case of $\mathrm{BH} 19$ of Elamkulam, even if the ground water table is lowered to $2 x$ and $3 x(x=1 \mathrm{~m}$ in this case), the factor of safety is less than except in the top 1 or
2 layers. A similar trend was also observed in the $\mathrm{BH} 33$ of Puthiyakavu ( $x=1$ in this case). These results indicate that the lowering of ground water table does not improve the factor of safety against liquefaction in some of the places.

Table 9 summarizes the effect of change in earthquake parameters and ground water table on other liquefaction parameters such as probability of liquefaction, lateral spreading, vertical settlement and LSI (only results of $\mathrm{BH} 1$ of Kaloor is discussed here). It is clear from the table that the probability of liquefaction and LSI vary much only when the earthquake magnitude changes. When there is a change in PGA and ground water table, the change in probability of liquefaction is insignificant and LSI remains same. But the other two parameters, i.e., lateral spreading and vertical settlement, is dependent on all the three parameters (earthquake magnitude, PGA and ground water table).

\section{Conclusions}

The liquefaction analyses were carried out in 37 boreholes in Ernakulam region and the results obtained (i.e., factor of safety against liquefaction, probability of liquefaction, lateral spreading, vertical settlement and LSI) is discussed 
Fig. 22 Parametric study results of $\mathrm{BH} 1$-Kaloor. a Variations in the factor of safety against liquefaction due to change in peak ground acceleration; $\mathbf{b}$ variations in the factor of safety against liquefaction due to change in earthquake magnitude; $\boldsymbol{c}$ variations in the factor of safety against liquefaction due to change in ground water table

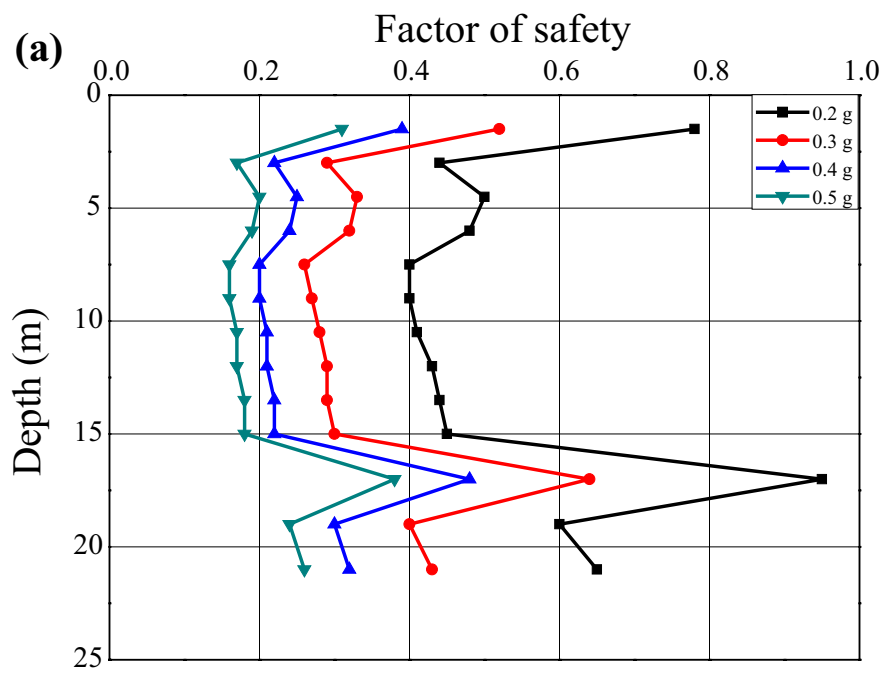

(b)

\section{Factor of safety}

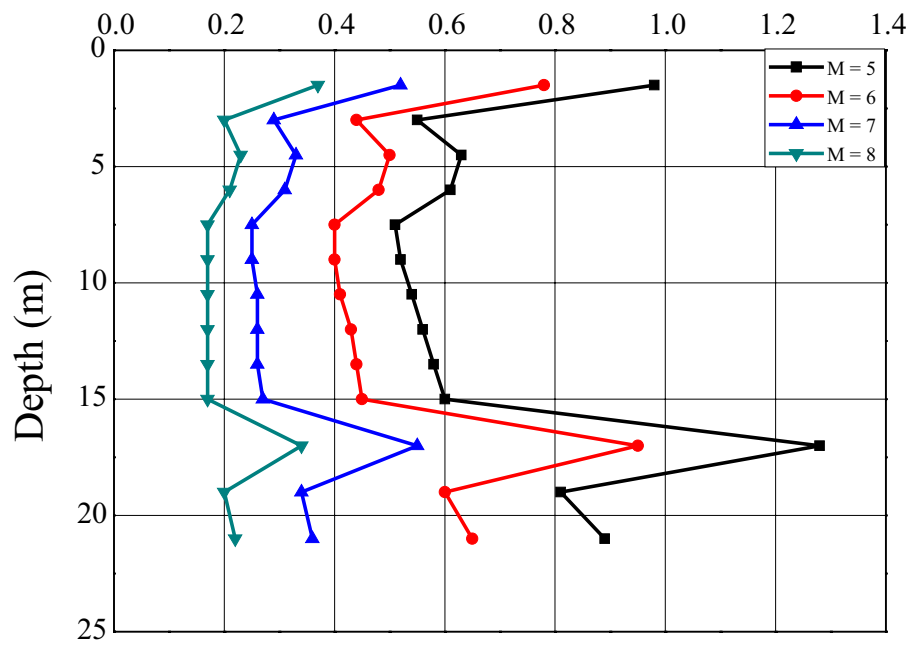

Factor of safety

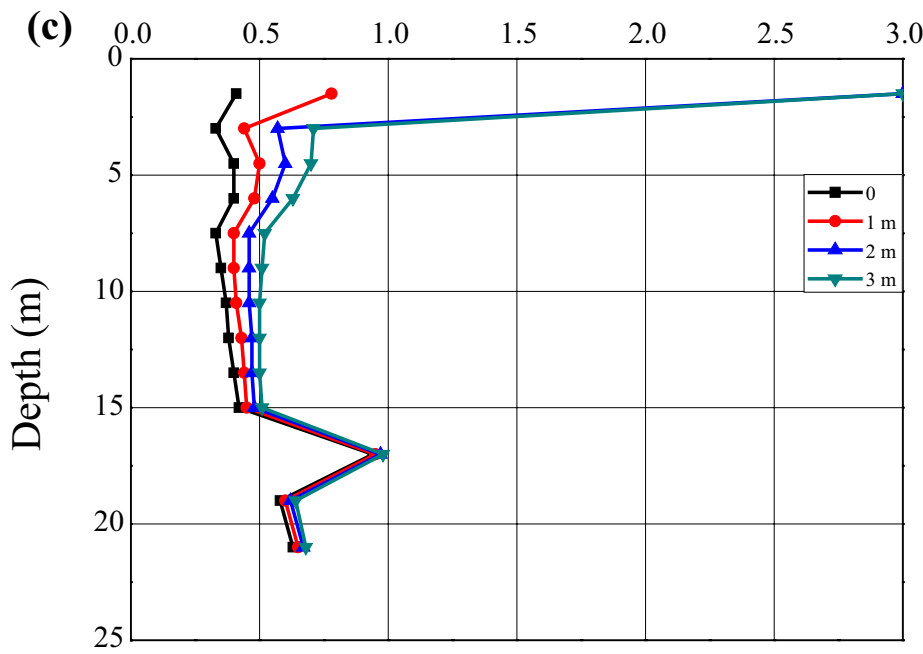


Fig. 23 Parametric study results of BH 19-Elamkulam. a Variations in the factor of safety against liquefaction due to change in peak ground acceleration; $\mathbf{b}$ variations in the factor of safety against liquefaction due to change in earthquake magnitude; $c$ variations in the factor of safety against liquefaction due to change in ground water table

\section{Factor of safety}

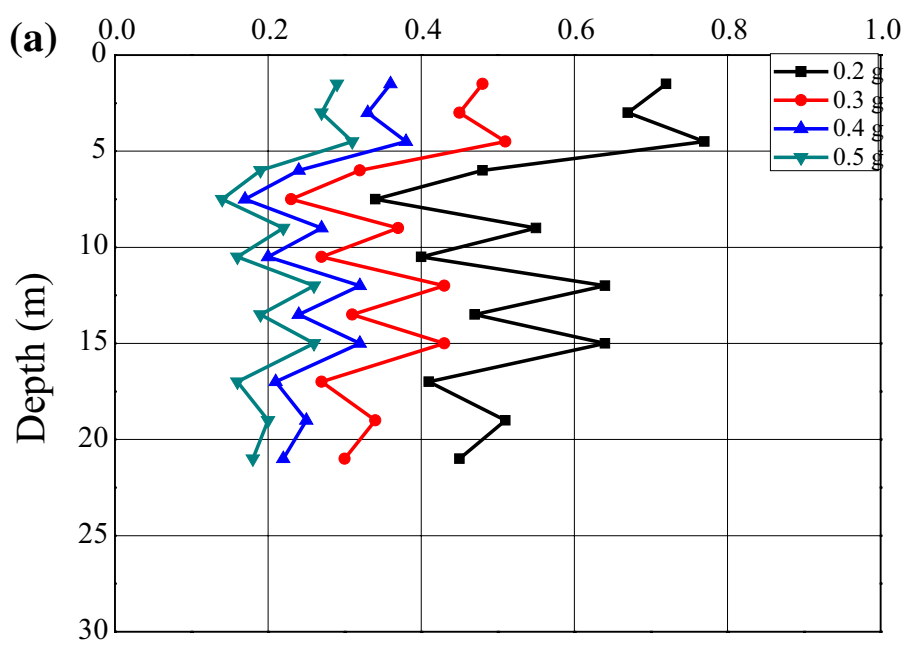

Factor of safety

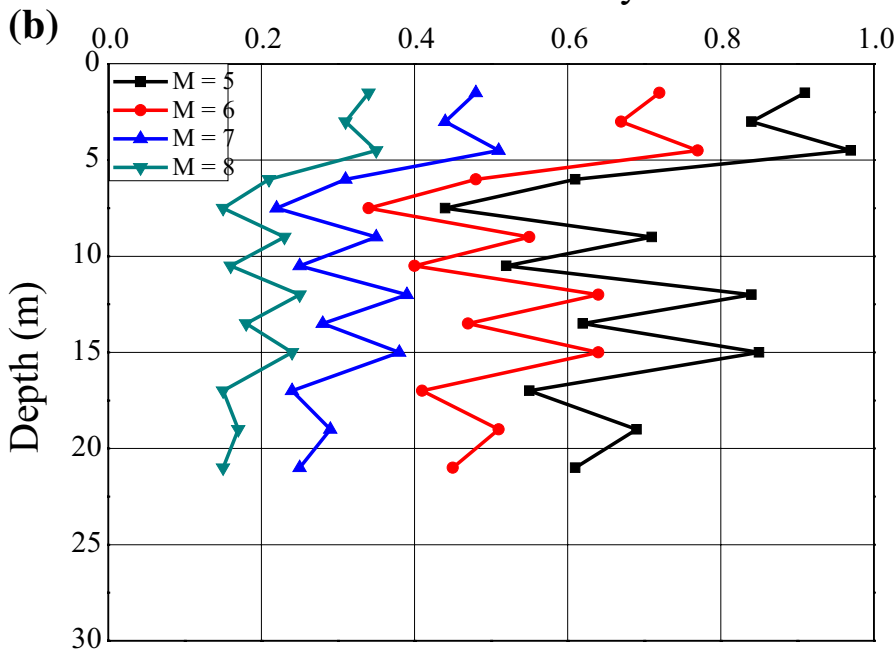

Factor of safety

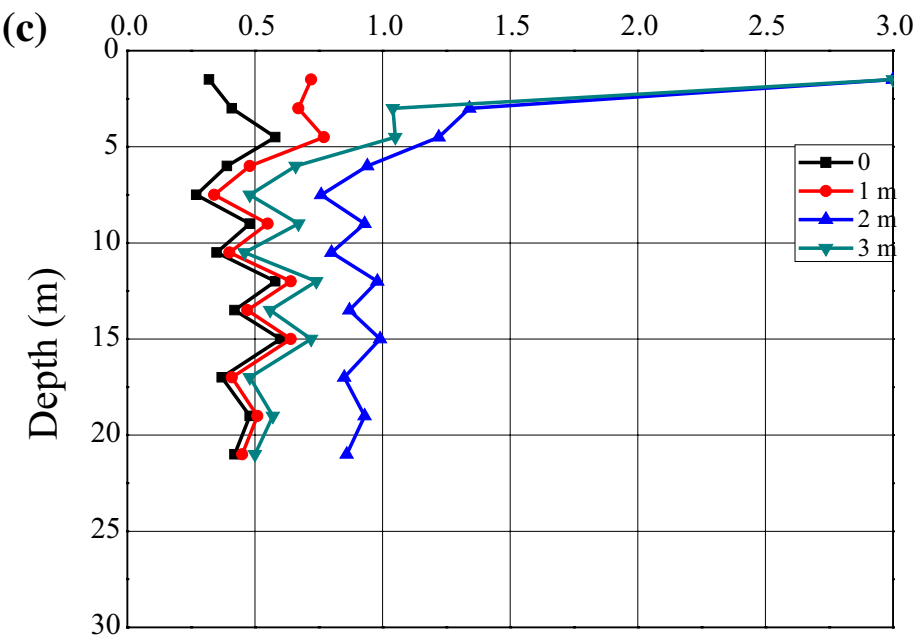


Fig. 24 Parametric study results of $\mathrm{BH} 33$-Puthiyakavu. a Variations in the factor of safety against liquefaction due to change in peak ground acceleration; $\mathbf{b}$ variations in the factor of safety against liquefaction due to change in earthquake magnitude; $c$ variations in the factor of safety against liquefaction due to change in ground water table

\section{Factor of safety}

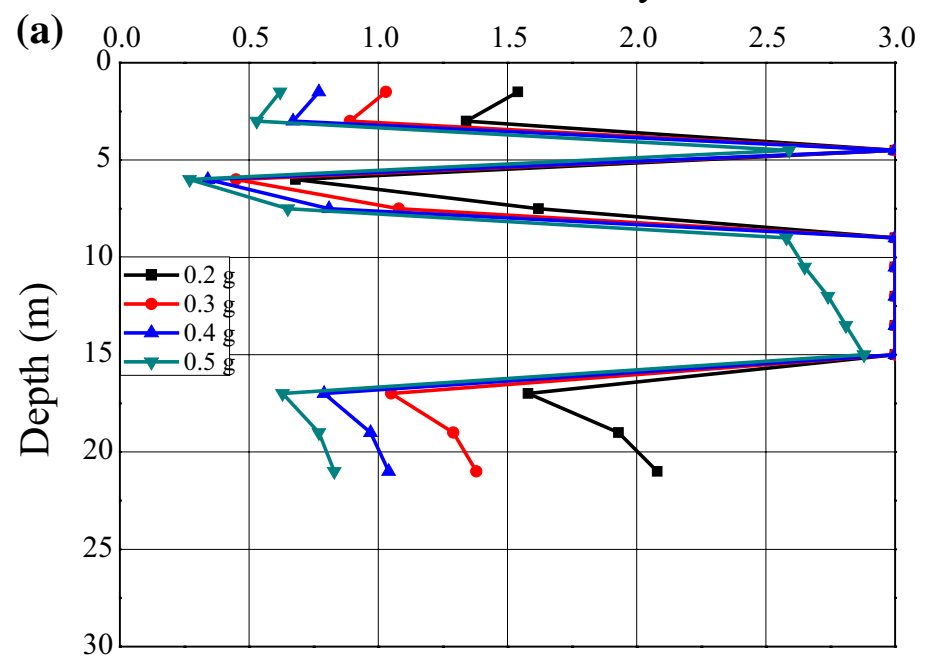

\section{Factor of safety}

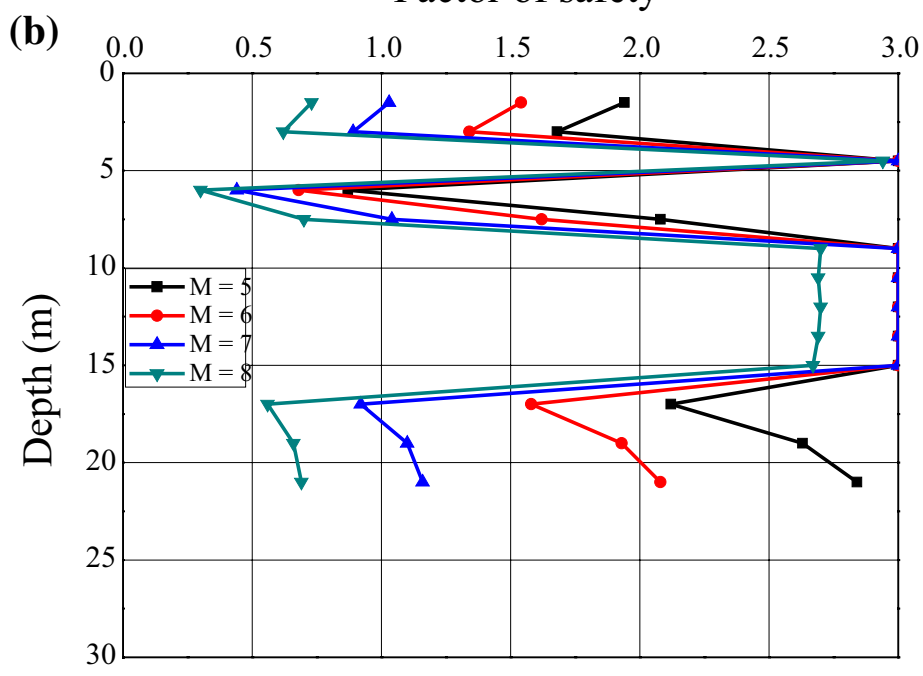

Factor of safety

(c)

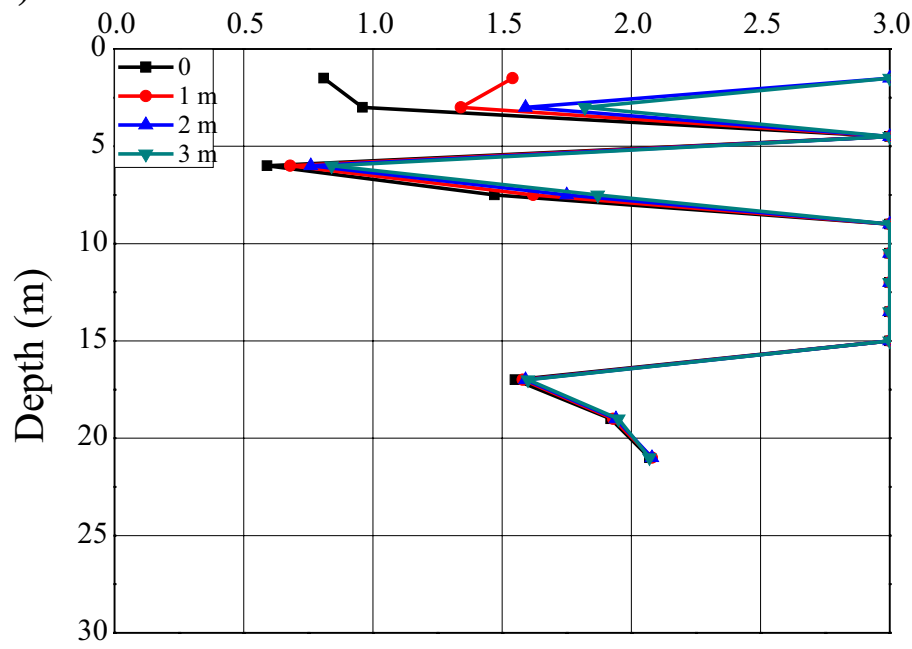


Table 9 Effect on liquefaction parameters (results of $\mathrm{BH} 1-$ Kaloor)

\begin{tabular}{|c|c|c|c|c|c|c|}
\hline \multicolumn{3}{|c|}{ Input } & \multicolumn{4}{|l|}{ Results } \\
\hline$M_{\mathrm{w}}$ & PGA (g) & GWT (m) & PL (\%) & $\mathrm{LS}(\mathrm{cm})$ & VS $(\mathrm{cm})$ & LSI \\
\hline 6 & 0.2 & 1 & 72.76 & 11 & 6 & 3 \\
\hline 5 & 0.2 & 1 & 45.13 & 2 & 1 & 1 \\
\hline 7 & 0.2 & 1 & 96.33 & 482 & 63 & 33 \\
\hline 8 & 0.2 & 1 & 99.60 & 743 & 70 & 80 \\
\hline 6 & 0.3 & 1 & 75.20 & 318 & 50 & 3 \\
\hline 6 & 0.4 & 1 & 75.76 & 658 & 70 & 3 \\
\hline 6 & 0.5 & 1 & 75.76 & 743 & 70 & 3 \\
\hline 6 & 0.2 & 0 & 74.17 & 78 & 32 & 3 \\
\hline 6 & 0.2 & 2 & 75.60 & 5 & 3 & 3 \\
\hline 6 & 0.2 & 3 & 75.09 & 3 & 2 & 3 \\
\hline
\end{tabular}

in this paper. It can be concluded that all areas are prone to liquefaction if an earthquake with PGA of $0.2 \mathrm{~g}$ and a magnitude of 6 hits the areas, except Manorama Junction, Puthiyakavu and some areas near Kacheripadi. The main reasons include the low SPT $N$ values (which reflect the soil conditions) and low ground water table. The places like Kacheripadi, Puthiyakavu, etc. where soils are in dense conditions showed a high factor of safety against liquefaction. The presence of laterite also improves the liquefaction resistance. A detailed parameter analysis was also carried out to study the effect of PGA, earthquake magnitude and ground water table on liquefaction susceptibility and other liquefaction parameters. The obtained values of the factor of safeties can be used to find the factor of safety against liquefaction for an earthquake with other $\mathrm{a}_{\max }$ and earthquake magnitude.

Acknowledgements The authors would like to extend their deep gratitude to M/s ENGINEERS DIAGNOSTIC CENTRE (P) LTD and Dr. ANIL JOSEPH for the SPT data supplied. Also, sincere gratitude is extended to Ms. Jisha John, Research Scholar, Dept. of Civil Engineering, NIT Calicut, India for the help rendered in the map preparation stage using ArcGIS software.

\section{Compliance with ethical standards}

Conflict of interest The authors declare that they have no conflict of interest.

\section{References}

1. Vipin KS, Sitharam TG (2013) Delineation of seismic source zones based on seismicity parameters and probabilistic evaluation of seismic hazard using logic tree approach. J Earth Syst Sci 122:661-676

2. Gangrade BK, Arora SK (2000) Seismicity of the Indian peninsular shield from regional earthquake data. Pure appl Geophys 157:1683-1705

3. Nair KK (1996) Geomorphology and evolution of coastal plane of Kerala. Geol Surv India Spec Publ 40:83-94
4. Erattupuzha J, George V (1979) Shoreline changes in Kerala coast. GSI special publication, vol 5, pp 83-86

5. Pawar SD, Venkataramana TM, Mallikarjuna C (1983) Systematic geological mapping around Shertall, Vikkom, Alleppey, Kottayam and Pandalam areas in parts of Alleppy and Kottayam Districts: Unpublished report of G.S.I

6. Mathai T, Nair SB (1988) Stages in the emergence of the CochinKodungallur coast-evidence for the interaction of marine and fluvial process. Proc Indian Nat Sci Acad 54:439-447

7. Rajendran CP, Rajagopalan G, Narayanaswamy (1989) Quaternary geology of Kerala. Evidence from radiocarbon dates. J Geol Soc India 33:218-222

8. Kunte PD (1995) On some aspects of barrier Islands of the west coast, India. J Coast Res 11:508-515

9. Ganesha Raj K, Paul MA, Hegde VS, Nijagunappa R (2001) Lineaments and seismicity of Kerala - a remote sensing based analysis. J Indian Soc Remote Sens 29:203-211

10. Rajendran CP, John B, Sreekumari K, Rajendran K (2009) Reassessing the earthquake hazard in Kerala based on the historical and current seismicity. J Geol Soc India 73:785-802

11. Sreevalsa K, Sitharam TG (2011) Probabilistic evaluation of seismic hazard in and around Kerala. In: Proceedings of Indian geotechnical conference, December 15-17, 2011, Kochi (paper no. F-080)

12. Anbazhagan P, Moustafa SSR, Al-Arifi NSN (2015) Seismic intensity map of South India for estimated future earthquakes. Arab J Geosci 8:9365-9371

13. Biju J, Rajan BA, Subrahmanyam DS, Yogendra S, Praseeda E, Divyalakshmi KS, Nelliat EPS, Pijush S, Ganapathy GP (2016) Seismicity of Kerala-an update. In: Proceedings of international conference on recent advances in rock engineering (RARE 2016), Bengaluru

14. Kramer SL (1996) Geotechnical earthquake engineering. Prentice Hall, Upper Saddle River

15. Marcuson WF (1978) Definition of terms related to liquefaction. J Geotech Eng Div (ASCE) 104(9):1197-1200

16. Tolon M (2013) A comparative study on computer aided liquefaction analysis methods. Int J Hous Sci 37(2):121-135

17. Rastogi BK, Chadha RK, Sarma CSP (1995) Investigations of June 7, 1988 earthquake of magnitude 4.5 near Idukki Dam in Southern India. Pure Appl Geo Phys 145(1):109-122

18. Seed HB, Idriss IM (1971) Simplified procedure for evaluating soil liquefaction potential. J Soil Mech Found Div (ASCE) 107:1249-1273

19. NovoLiq User's Manual, developed by NovoTech Softwares

20. Youd TL, Noble SK (1997) Liquefaction criteria based on statistical and probabilistic analyses. Technical report NCEER-97-0022, 
National Center for Earthquake Engineering Research, SUNY, Buffalo, New York

21. Youd TL, Perkins DM (1987) Mapping of liquefaction severity index. J Geotech Eng 113(11):1374-1392

22. Zhang G, Robertson PK, Brachman RWI (2004) Estimating liquefaction-induced lateral displacements using the standard penetration test or cone penetration test. J Geotech Geoenviron Eng 130(8):861-871

23. Ishihara K, Yoshimine M (1992) Evaluation of settlements in sand deposits following liquefaction during earthquakes. Soils Found 32(1):173-188

24. Peck RB, Hanson WE, Thornburn TH (1974) Foundation engineering, 2nd edn. Wiley, New York

25. Seed HB (1979) Soil liquefaction and cyclic mobility evaluation for level ground during earthquakes. J Geotech Eng (ASCE) 105(GT2):201-255

26. Seed HB, Idriss IM, Arango I (1983) Evaluation of liquefaction potential using field performance data. J Geotech Eng (ASCE) 109(GT3):458-482

27. Seed HB, Tokimatsu K, Harder LF, Chung R (1985) Influence of SPT procedures in soil liquefaction resistance evaluations. J Geotech Eng (ASCE) 111(12):861-878

28. Ishihara K (1993) Liquefaction and flow failure during earthquakes. Geotechnique 43(3):351-415

29. Fear CE, McRoberts EC (1995) Reconsideration of initiation of liquefaction in sandy soils. J Geotech Eng (ASCE) 121(GT 3):249-261

30. Youd TL, Idriss IM (1997) Proceedings for the NCEER workshop on evaluation of liquefaction resistance of soils. Technical report: NCEER-97-0022, National Center for Earthquake Engineering Research State, University of New York, Buffalo

31. Youd TL, Idriss IM, Andrus RD et al (2001) Liquefaction resistance of soils: summary report from the 1996 NCEER and 1998 NCEER/ NSF workshops on evaluation of liquefaction resistance of soils. J Geotech Geoenviron Eng (ASCE) 127(10):817-833

32. Cetin KO, Seed RB, Der Kiureghian A, Tokimatsu K, Harder LF, Kayen RE, Moss RES (2004) Standard penetration test-based probabilistic and deterministic assessment of seismic soil liquefaction potential. J Geotech Geoenviron Eng (ASCE) 130(12):1314-1340

33. Carraro JAH, Bandini P, Salgado R (2003) Liquefaction resistance of clean and nonplastic silty sands based on cone penetration resistance. J Geotech Geoenviron Eng (ASCE) 129:965-976

34. Robertson PK (2009) Performance based earthquake design using the CPT. In: Proceedings of IS Tokyo conference, CRC Press/ Balkema, Taylor \& Francis Group, Tokyo

35. Robertson PK (2010) Evaluation of flow liquefaction and liquefied strength using the cone penetration test. J Geotech Geoenviron Eng (ASCE) 136:842-853

36. Stokoe KH, Wright SG, Bay JA, Roesset JM (1994) Characterization of geotechnical sites by SASW method, ISSMFE Technical Committee \#10 for XIII ICSMFE, geophysical characterization of sites. A. A. Balkema Publishers, Rotterdam, pp 15-25

37. Andrus RD, Stokoe KH, Riley MC, Bay JA (1998) Liquefaction evaluation of densified sand at approach to Pier 1 on Treasure Island, California, using SASW method. National Institute of Standards and Technology, Gaithersburg

38. Kayen R, Tanaka Y, Kishida T, Sugimoto S (2002) Liquefaction potential of native ground in West Kobe, Japan by the spectral analysis of surface waves (SASW) method. In: Proceedings of the 8th U.S.-Japan workshop on earthquake resistant design of lifeline facilities and countermeasures against liquefaction, Tokyo
39. Kayen R, Thompson E, Minasian D, Moss RES, Collins BD, Sitar N, Dreger D, Carver G (2004) Geotechnical reconnaissance of the 2002 Denali Fault, Alaska earthquake. Earthq Spectra 20(3):639-667

40. Liu N, Mitchell JK (2006) Influence of nonplastic fines on shear wave velocity-based assessment of liquefaction. J Geotech Geoenviron Eng (ASCE) 132:1091-1097

41. Kayen R, Moss RES, Thompson EM, Seed RB, Cetin KO, Der Kiureghian A, Tanaka Y, Tokimatsu K (2013) Shear wave velocity based probabilistic and deterministic assessment of seismic soil liquefaction potential. J Geotech Geoenviron Eng (ASCE) 139:407-419

42. Boominathan A, Rangaswamy K, Rajagopal K (2010) Effect of non-plastic fines on liquefaction resistance of Gujarat sand. Int J Geotech Eng 4:241-253

43. Dash HK, Sitharam TG (2009) Undrained cyclic pore pressure response of sand-silt mixtures: effect of non-plastic fines and other parameters. J Geotech Geol Eng 27:501-517

44. Polito CP, Martin JR (2001) Effects of nonplastic fines on the liquefaction resistance of sands. J Geotech Geoenviron Eng 127:408-415

45. Seed HB, Arango I (1976) Evaluation of soil liquefaction potential for level ground during earthquakes: a summary report. Prepared by U.S. Nuclear Regulatory Commission under contract no. AT(04-3)-954

46. Henke W, Henke R (1992) Prototype cyclic torsional cylindrical shear tests. In: Proceedings of 10th world conference on earthquake engineering, Rotterdam

47. Peacock WH, Seed HB (1968) Sand liquefaction under cyclic loading simple shear conditions. J Soil Mech Found Div (ASCE) 94(SM3):689-708

48. Finn WDL, Pickering DJ, Bransby PL (1971) Sand liquefaction in triaxial and simple shear tests. J Soil Mech Found Div (ASCE) 97(SM4):639-659

49. De Alba P, Seed HB, Chan CK (1976) Sand liquefaction in large scale simple shear tests. J Geotech Eng Div (ASCE) 102:909-927

50. Kim J, Kawai T, Kazama M (2017) Laboratory testing procedure to assess post-liquefaction deformation potential. Soils Found 57:905-919

51. Susumu Y, Kenji I, Iwao M, Rolando O, Masatoshi I, Shuji T (2000) Large-scale shaking table tests on pile foundations in liquefied ground. In: Proceedings of 12th world conference on earthquake engineering, New Zealand

52. Hakam A (2016) Laboratory liquefaction test of sand based on grain size and relative density. J Eng Technol Sci 48(3):334-344

53. Hakam A, Ismail FA, Fauzan (2016) Liquefaction potential assessment based on laboratory test. Int J Geomate 11(26):2553-2557

54. Sharp MK, Dobry R, Phillips R (2010) CPT-based evaluation of liquefaction and lateral spreading in centrifuge. J Geotech Geoenviron Eng (ASCE) 136:1334-1346

55. Hayden CP, Zupan JD, Bray JD, Allmond JD, Kutter BL (2014) Centrifuge tests of adjacent mat-supported buildings affected by liquefaction. J Geotech Geoenviron Eng (ASCE) 141:04014118

56. Nova R, Wood DM (1979) A constitutive model for sand in triaxial compression. Int J Numer Anal Methods Geomech 3:255-278

57. Alarcon-Guzman A, Leonards G, Chameau JL (1988) Undrained monotonic and cyclic strength of sands. J Geotech Eng (ASCE) 114:1089-1109

58. Jefferies MG (1993) Nor-Sand: a simple critical state model for sand. Géotechnique 43:91-103

59. Lade PV (1977) Elasto-plastic stress-strain theory for cohesionless soil with curved yield surfaces. Int J Solids Struct 13:1019-1035 
60. Pastor M, Zienkiewicz OC, Leung KH (1985) Simple model for transient soil loading in earthquake analysis. II. Non-associative models for sands. Int J Numer Anal Methods Geomech 9:477-498

61. Zienkiewicz OC, Leung KH, Pastor M (1985) Simple model for transient soil loading in earthquake analysis. I. Basic model and its application. Int J Numer Anal Methods Geomech 9:953-976

62. Darve F, Labanieh S (1982) Incremental constitutive law for sands and clays: simulations of monotonic and cyclic tests. Int J Numer Anal Methods Geomech 6:243-275

63. Darve $F(1990)$ Incrementally non-linear constitutive relationships. In: Darve F (ed) Geomaterials constitutive equations and modelling. Elsevier Applied Science, London, pp 213-238
64. Kolymbas D (1991) An outline of hypoplasticity. Arch Appl Mech 61:143-151

65. Herle I, Gudehus G (1999) Determination of parameters of a hypoplastic constitutive model from properties of grain assemblies. Mech Cohesive Frict Mater 4:461-486

Publisher's Note Springer Nature remains neutral with regard to jurisdictional claims in published maps and institutional affiliations. 